Vanessa Correia Loureiro

\title{
Rastreamento de mutações nos genes VHL, SDHB e SDHD em pacientes portadores de feocromocitoma ou também, paraganglioma esporádico
}

\author{
Dissertação apresentada à Disciplina de \\ Endocrinologia da Faculdade de Medicina da \\ Universidade de São Paulo para obtenção do \\ título de Mestre em Ciências \\ Área de concentração: Endocrinologia \\ Orientador: Dra. Maria Lúcia C. Corrêa Giannella
}


Vanessa Correia Loureiro

\title{
Rastreamento de mutações nos genes VHL, SDHB e SDHD em pacientes portadores de feocromocitoma ou também, paraganglioma esporádico
}

\author{
Dissertação apresentada à Disciplina de \\ Endocrinologia da Faculdade de Medicina da \\ Universidade de São Paulo para obtenção do \\ título de Mestre em Ciências \\ Área de concentração: Endocrinologia \\ Orientador: Dra. Maria Lúcia C. Corrêa Giannella
}


Aos meus pais Alice e Joaquim 


\section{Agradecimentos}

A Deus, por todas as graças a mim concedidas ao longo de minha vida;

A Dra. Maria Lúcia C. Corrêa Giannella (Malu), pela chance, orientação, amizade e confiança ao longo desses anos;

A Dra. Maria Adelaide Albergaria Pereira, pelo auxílio constante no contato com os pacientes;

A Dra. Andrea Cecília Toscanini pela confiança e por ter me ensinado os primeiros passos na Biologia Molecular;

A biologista Ana Mercedes Sousa Cavaleiro, que foi mais que um braço direito neste estudo;

A biologista Maria Ângela Henrique Zanella Fortes, que sempre me socorreu com paciência e acima de tudo pela sua amizade que para mim será eterna;

Ao biologista Ricardo Rodrigues Giorgi que nunca exitou em tirar minhas dúvidas, e me ajudou sempre com muita paciência;

Ao pós-graduando Cássio N. Coimbra, que me ensinou a metodologia de dHPLC;

A técnica Maria Auxiliadora Rangel Higa que sempre se dipôs a me ajudar;

A Dra. Ileana Rubió, pela ajuda na leitura dos seqüênciamentos;

Aos meus amigos David, Jonathan, Érika e Junior, minhas cunhadas Paola e Neia e minha sobrinha Tarcila pelos momentos de descontração durante os períodos mais difíceis; 
Aos meus pais que com muito amor, trabalho e dedicação me proveram meios para chegar onde estou hoje, e aos meus irmãos Dudu e Ricardo sempre presentes me auxiliando da melhor forma;

Ao meu pai com sua ajuda importantíssima com minhas dificuldades com a língua inglesa e meu irmão Dudu pelos reparos feitos por ele em meu computador;

Ao meu noivo Eduardo, que pacientemente suportou meus momentos de tensão durante a finalização do meu projeto, e esteve sempre ao meu lado me ajudando da melhor forma;

A Capes pelo apoio financeiro. 
Esta dissertação está de acordo com as seguintes normas, em vigor no momento desta publicação:

Referências: adaptado de International Committee of Medical Editors (Vancouver)

Universidade de São Paulo. Faculdade de Medicina. Serviço de Biblioteca e documentação. Guia de apresentação de dissertações, teses e monografias. Elaborado por Annelise da Cunha, Maria Julia de A. L. Freddi. Maria Julia de A. L. Freddi, Maria F. Crestana, Marinalva de Souza Aragão, Suely Campos Cardoso, Valéria Vilhena. $2^{\text {a }}$ ed. São Paulo: Serviço de Biblioteca e Documentação; 2005.

Abreviaturas dos títulos dos periódicos de acordo com List of Journals Indexed in Index Medicus. 
SUMÁRIO 


\section{Sumário}

Lista de abreviaturas, símbolos e siglas

Lista de figuras

Lista de tabelas

Lista de gráficos

Resumo

Summary

1. INTRODUÇÃO.

1.2. Síndromes genéticas associadas ao feocromocitoma e ao

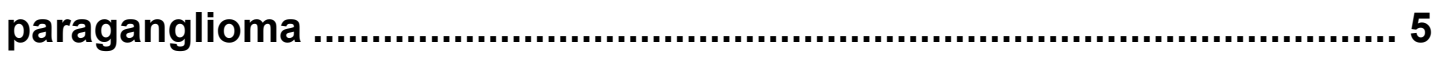

1.2.1. Doença de von Hippel Lindau .................................................... 6

1.2.2. Mutações nos genes do complexo II mitocondrial (Succinato-

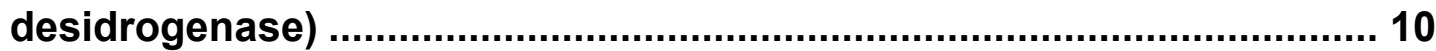

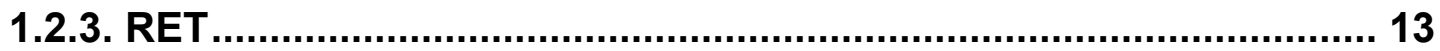

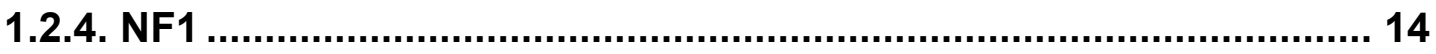

1.3. Estudos Genéticos em Feocromocitomas Esporádicos ................ 15

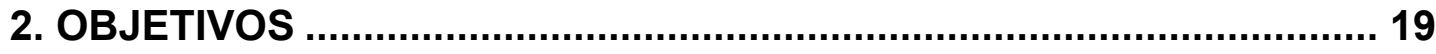

3. CASUÍSTICA, MATERIAIS E MÉTODOS ........................................... 21

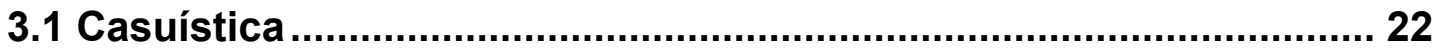

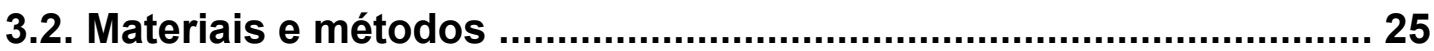

3.2.1 Extração de DNA genômico a partir de leucócitos de sangue periférico

3.2.2 Reação em Cadeia da Polimerase (PCR) ..................................... 26

3.2.3 Cromatografia líquida denaturante de alta performance (dHPLC) 33 
3.2.4. Seqüenciamento automático .................................................... 35

3.2.5 Análise estatística.................................................................. 36

4. RESULTADOS .......................................................................... 37

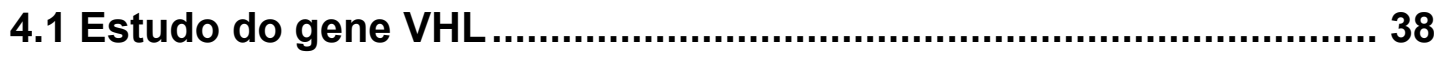

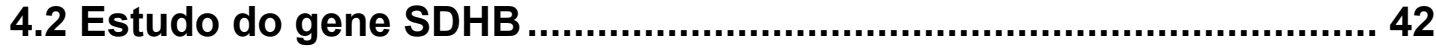

4.3 Estudo do gene SDHD ................................................................... 48

4.4 Resumo dos resultados ........................................................... 57

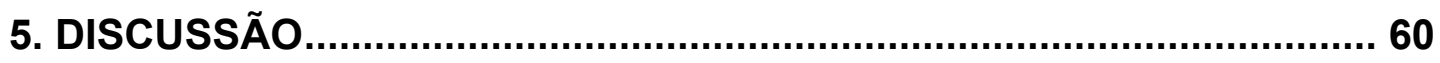

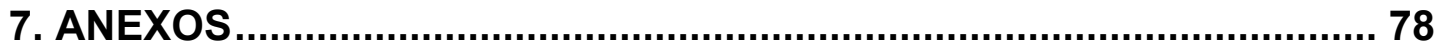

8. REFERÊNCIAS BIBLIOGRÁFICAS .............................................. 83 


\section{Lista de abreviaturas, símbolos e siglas}

\begin{tabular}{|c|c|}
\hline ATG & Códon de iniciação da tradução (Metionina) \\
\hline dATP & Desoxiadenosina trifosfatada \\
\hline dCTP & Desoxicitidina trifosfatada \\
\hline DCPAS & "Downstream core polyadenylation sequence" \\
\hline dGTP & Desoxiguanosina trifosfatada \\
\hline dHPLC & Cromatografia Líquida denaturante de alta performance \\
\hline DNA & Ácido desoxirribonucléico \\
\hline dTTP & Desoxitimidina trifosfatada \\
\hline EDTA & Etilenodiaminotetracético \\
\hline EGF & Fator de crescimento epidérmico \\
\hline EUA & Estados Unidos da América \\
\hline FMUSP & Faculdade de Medicina da Universidade de São Paulo \\
\hline GTPase & Guanosina trifosfatase \\
\hline $\mathrm{H}_{2} \mathrm{O}$ & Água \\
\hline $\mathrm{HC}$ & Hospital das Clínicas \\
\hline $\mathrm{HIF}-1 \alpha$ & Fator de transcrição hipóxia induzido \\
\hline q.s.p. & Quantidade suficiente para \\
\hline $\mathrm{MgCl}_{2}$ & Cloreto de magnésio \\
\hline Min & Minutos \\
\hline $\mathrm{mL}$ & Mililitros \\
\hline
\end{tabular}




\begin{tabular}{|c|c|}
\hline $\mathrm{mM}$ & Milimolar \\
\hline M & Molar \\
\hline $\mathrm{NIH}$ & National Institutes of Health \\
\hline RNA & Ácido ribonucléico \\
\hline mRNA & Ácido ribonucléico mensageiro \\
\hline $\mathrm{NaCl}$ & Cloreto de sódio \\
\hline NEM & Neoplasia endócrina múltipla \\
\hline NF1 & Neurofibromatose tipo 1 \\
\hline $\mathrm{ng} / \mu \mathrm{L}$ & Nanogramas por microlitro \\
\hline${ }^{\circ} \mathrm{C}$ & Graus Celsius \\
\hline $\mathrm{Pb}$ & Pares de bases \\
\hline PCR & Reação em cadeia da polimerase \\
\hline PDGF- $\beta$ & Fator de crescimento derivado de plaquetas- $\beta$ \\
\hline $\mathrm{pH}$ & Potencial hidrogenioiônico \\
\hline Ras & Proteína Ras \\
\hline Ras-GDP & Proteína Ras ligada à guanosina-difosfato \\
\hline Ras-GTP & Proteína Ras ligada à guanosina-trifosfato \\
\hline RET & Protooncogene RET \\
\hline Rpm & Rotações por minuto \\
\hline Seg & Segundos \\
\hline SDH & Succinato desidrogenase \\
\hline
\end{tabular}




\begin{tabular}{ll} 
SDHA & Succinato desidrogenase subunidade A \\
SDHB & Succinato desidrogenase subunidade B \\
SDHC & Succinato desidrogenase subunidade C \\
SDHD & Succinato desidrogenase subunidade D \\
SDS & Dodecil sulfato de Sódio \\
SNP & "Single nucleotide polymorphism" \\
Taq & DNA polimerase termus aquaticus \\
TE & Tampão Tris Etilenodiaminotetracético \\
TGF- $\alpha$ & Fator de crescimento transformante- $\alpha$ \\
UCPAS & "Upstream core polyadenylation sequence" \\
VCB & Complexo proteína VHL, Culina e Elongina B \\
VEGF & Fator de crescimento do endotélio vascular \\
VHL & Gene e proteína de von Hippel Lindau \\
$\mu L$ & Microlitros \\
11 q23 & Localização genômica do gene SDHD \\
$10 q 11.2$ & Localização genômica do gene RET \\
$17 q 11.2$ & Localização genômica do gene NF1 \\
1 p36 & Localização genômica do gene SDHB \\
$3 p 25-26$ & Locus de susceptibilidade para o feocromocitoma \\
$16 p 13$ & a genômica do gene VHL \\
\hline
\end{tabular}




\section{Lista de figuras}

Figura 1 - $\quad$ O gene VHL é um gene supressor tumoral, localizado no cromossomo 3p25-26.

Figura 2 - Interação da proteína VHL com outras proteínas

Figura 3 - Localização do gene SDHB.

Figura 4 - Localização do gene SDHD

Figura 5 - Possíveis formações após pareamento entre alelos na Cromatografia liquida denaturante de alta performance (dHPLC)

Figura 6 - Painel A: Padrões de cromatograma ao dHPLC do amplicon VHL1A amplificado a partir de DNA obtido de dois controles normais.

Painel B: Eletroferogramas do amplicon VHL1A demonstrando a troca da base $G$ pela base A 195 nucleotídeos 5' ao códon de início da tradução (c - 195 $\mathrm{G}>\mathrm{A}$ ) em heterozigose e em homozigose. 
Figura 7 - Painel A: Padrões de cromatograma ao dHPLC do amplicon VHL1B (13, 14, 15 e 33) comparados com o cromatograma de um controle normal.

Painel B: Eletroferograma representativo do amplicon VHL 1B dos pacientes 14 e 31, demonstrando a troca da base $C$ pela base $T$ em heterozigose (c. -77 $\mathrm{C}>\mathrm{T})$.

Figura 8 - Painel A: Cromatogramas ao dHPLC do amplicon SDHB 3 dos pacientes 10, 11 e 35 comparados ao cromatograma do controle normal.

Painel B: Eletroferograma representativo do amplicon SDHB 3 dos pacientes 10, 11 e 35, demonstrando a troca da base $G$ pela base $T$, em heterozigose no exon 2 (c.201-36 G>T)

Figura 9 - Painel A: Cromatogramas ao dHPLC do amplicon SDHB 4 do paciente 6 com picos complexos (heteroduplex).

Painel B: Eletroferograma do amplicon SDHD 4 do paciente 6 demonstrando a substituição da base $G$ pela base A no nucleotídeo 293 (c. 293 G>A) em heterozigose. 
Figura 10 - Painel A: Cromatogramas ao dHPLC do amplicon SDHB 5 dos pacientes 15 e 35 com picos complexos (heteroduplex) comparados ao cromatograma do controle normal. Painel B: Eletroferograma do amplicon SDHB 5 do paciente 35 demonstrando a troca da base G pela base A, em heterozigose, (c.540 G>A). Painel C: Eletroferograma do amplicon SDHB 5 do paciente 15 demonstrando a substituição da base $T$ pela base $\mathrm{C}$, em heterozigose, $(\mathrm{c} .487 \mathrm{~T}>\mathrm{C})$

Figura 11 - Painel A: Cromatograma ao dHPLC do amplicon SDHD 3 do paciente 24 comparado ao cromatograma do controle normal. Painel B: Eletroferograma do amplicon SDHD 3 do paciente 24 demonstrando a troca da base C pela base T, em heterozigose, no nucleotídeo 204 (c.204 C>T). 
Figura 12 - Painel A: Cromatograma ao dHPLC do amplicon SDHD 4A do paciente 16 comparado ao cromatograma do controle normal. Painel B: Cromatograma ao dHPLC do amplicon SDHD 4C do paciente 16 comparado ao cromatograma do controle normal. Painel C: Eletroferograma do amplicon SDHD 4A do paciente 16 demonstrando a substituição em heterozigose da base T pela base $C$ no nucleotídeo 32 localizado 5 ' ao primeiro nucleotídeo do exon 4 (c.315 - 32 T>C). Painel D: Eletroferograma do amplicon SDHD 4C do paciente 16 demonstrando a substituição em heterozigose da base A pela base $\mathrm{G}$ no nucleotídeo 803 localizado 3' ao códon de término da tradução (TGA) (c. ${ }^{*} 803$ $A>G)$

Figura 13 - Eletroferograma do amplicon SDHD 4C do paciente 31 demonstrando a substituição da base $C$ pela base $T$ em heterozigose no nucleotídeo 612 localizado 3' ao códon do término da tradução (TGA) (c. $\left.{ }^{*} 612 \mathrm{C}>\mathrm{T}\right)$.

Figura 14 - Eletroferograma do amplicon SDHD 4C do paciente 6 demonstrando a substituição da base $T$ pela base $\mathrm{C}$, em heterozigose, no nucleotídeo 799 localizado 3' ao códon de término da tradução (TGA) (c. ${ }^{* 799}$ T>C). 
Figura 15 - Seqüência do exon 4 e da região 3' não codificante do gene SDHD.

Figura 16 Desenho representativo da reação de poliadenilação de mRNA de mamíferos.

Figura 17 - Estrutura secundária proposta para o pré-mRNA transcrito a partir do alelo $A$ do gene SDHD... 


\section{Lista de tabelas}

Tabela 1 - Dados demográficos dos pacientes, apresentação clínica e classificação histológica dos tumores estudados

Tabela 2 - Iniciadores utilizados para a amplificação dos exons do gene $\mathrm{VHL}$ e respectivas temperaturas de anelamento e números de pares de base dos fragmentos amplificados

Tabela 3 - Iniciadores utilizados para a amplificação dos exons do gene SDHB e respectivas temperaturas de anelamento $\mathrm{e}$ números de pares de base dos fragmentos amplificados.

Tabela 4 - Iniciadores utilizados para a amplificação dos exons do gene SDHD e respectivas temperaturas de anelamento e números de pares de base dos fragmentos amplificados .

Tabela 5 - Resumo das alterações encontradas no gene SDHB

Tabela 6 - Pacientes com a substituição c. *803 A>G localizada no amplicon $4 \mathrm{C}$ do gene SDHD

Tabela 7 - Resumo das alterações encontradas no gene SDHD....... 
Tabela 8 - Resumo dos resultados encontrados nos 38 pacientes estudados 


\section{Lista de Gráficos}

Gráfico 1 - Gráfico representativo dos resultados obtidos por Neumann et al., 2002.

Gráfico 2 - Gráfico representativo dos resultados obtidos por Amar et al., 2005..................................................... 17 
RESUMO 


\section{Resumo}

Loureiro, VC. Rastreamento de mutações nos genes VHL, SDHB e SDHD em pacientes portadores de feocromocitoma ou, também, paraganglioma esporádico. [Dissertação] São Paulo: "Faculdade de Medicina, Universidade de São Paulo"; 2006.

Os feocromocitomas são tumores neuroendócrinos constituídos de células cromafins secretoras de catecolaminas e neuropeptídeos diversos, cuja manifestação clínica mais comum é a hipertensão. Doze a $24 \%$ dos tumores aparentemente esporádicos, apresentam mutações germinativas em genes até então associados a síndromes herdadas, como, RET, VHL, SDHB e SDHD. A doença de von Hippel-Lindau é causada por mutações no gene VHL. As proteínas codificadas pelos genes SDHB e SDHD fazem parte do complexo mitocondrial II e da cadeia aeróbica de transporte de elétrons. O objetivo deste projeto de pesquisa foi o rastreamento de mutações nos genes VHL, SDHB e SDHD em pacientes portadores de feocromocitoma ou, também, paraganglioma esporádicos acompanhados no Serviço de Endocrinologia do Hospital das Clínicas da FMUSP. Todos os exons dos três genes estudados foram amplificados por PCR e analisados por dHPLC. Os amplicons que apresentaram cromatogramas suspeitos ao dHPLC foram submetidos ao seqüenciamento automático. Nenhuma mutação foi encontrada no gene VHL, apenas dois polimorfismos previamente descritos no exon 1, c. -77 C>T em dois pacientes e c - $195 \mathrm{G}>\mathrm{A}$ em $58,6 \%$ do total de alelos dos pacientes estudados. No gene SDHB foram encontrados dois 
polimorfismos previamente descritos (c. 201-36 G>T e c.487 T>C) em quatro pacientes, uma mutação silenciosa não descrita (c.540 G>A) e uma mutação previamente descrita em portadores de feocromocitoma (c. 293 G>A). Um mesmo paciente apresentou a mutação silenciosa c.540 G>A e o polimorfismo c.201-36 G>T. No gene SDHD foram encontrados dois polimorfismos descritos (c.204 C>T e c.315-32 T>C) em um paciente cada, uma variante alélica descrita na literatura na região 3' não codificante cuja freqüência nunca foi estudada em outras populações (c. *612 C>T) e duas substituições nunca descritas na região 3' não codificante (c. *799 T>C e c. $\left.{ }^{*} 803 \mathrm{~A}>\mathrm{G}\right)$. As variantes c. ${ }^{*} 612 \mathrm{C}>\mathrm{T}$ e c. ${ }^{*} 799 \mathrm{~T}>\mathrm{C}$ foram detectadas em apenas um paciente cada e não foram encontradas em 200 alelos de controles normais estudados. A variante $c .{ }^{\star} 803 A>G$ foi encontrada em nove de 76 alelos dos 38 pacientes $(11,8 \%)$ e em cinco de 200 alelos de 100 controles não afetados (2,5\%), sendo, portanto, um polimorfismo significativamente mais freqüente entre os portadores de feocromocitoma ou paraganglioma. Dentre os sete pacientes portadores do polimorfismo c. *803 $A>G$, três pacientes heterozigotos para este polimorfismo apresentaram um segundo polimorfismo no gene SDHD, sendo que um desses pacientes também apresentava uma mutação no gene SDHB. Dentre os demais quatro pacientes, dois apresentavam o polimorfismo c. ${ }^{*} 803$ A $>G$ em homozigose. Este polimorfismo ocorre no nucleotídeo localizado na posição -1 imediatamente 5' ao Sítio de Clivagem do pré-mRNA para que ocorra a inserção da cauda Poli(A), fundamental para a estabilidade do mRNA. A substituição da base $A$ pela base $G$ muito provavelmente apresenta uma 
repercussão funcional, pois a base A na posição -1 é considerada como a mais eficiente na promoção da clivagem do pré-mRNA, enquanto a base G é considerada a menos eficiente (ordem de eficiência de clivagem $\mathrm{A}>\mathrm{U}>\mathrm{C}>$ G). Desta forma, a possibilidade desse polimorfismo conferir susceptibilidade ao desenvolvimento do feocromocitoma e do paraganglioma não está descartada, sendo provável que outros eventos genéticos sejam necessários para promover a tumorigênese. Em conclusão, esse estudo evidenciou uma baixa freqüência de mutações nas regiões codificantes dos genes VHL (mutações não detectadas), SDHB $(5,2 \%)$ e SDHD (mutações não detectadas) nessa série de pacientes com feocromocitomas e paragangliomas esporádicos, porém, encontrou um polimorfismo na região 3' não codificante do gene SDHD significativamente mais freqüente nos portadores desses tumores que em indivíduos controles não afetados, e que, por suas características, pode estar relacionado à etiopatogenia do feocromocitoma e do paraganglioma.

Descritores: feocromocitoma; paraganglioma; mutações; donça de vonHippel Lindau; Succinato desidrogenase; hipertensão. 


\section{Summary}

Loureiro, VC. Mutation screening in the VHL, SDHB and SDHD genes in patients with sporadic pheochromocytoma and/or paraganglioma. [Dissertation]. Sao Paulo: "Faculdade de Medicina, Universidade de Sao Paulo"; 2006

Pheochromocytomas are neuroendocrine tumors composed of chromaffin cells that produce and secrete catecholamines as well as a variety of neuropeptides, whose most common clinical manifestation is arterial hypertension. Twelve to $24 \%$ of the apparently sporadic pheochromocytomas, present germline mutations in genes previously associated to inherited familiar syndromes, such as, RET, VHL, SDHB e SDHD. The von Hippel-Lindau (VHL) disease occurs upon the VHL gene mutation - a tumor suppressor gene whose product encodes complexes with other proteins leading proteic substracts to the proteolysis. The proteins encoded by the SDHD and SDHB genes are parts of the complex mitochondrial II, as well as the aerobic chain of the electron transport. The aim of the present study was the screening of mutations in the VHL, SDHB and SDHD genes in patients harboring sporadic pheochromocytoma and/or paraganglioma, followed by the Endocrinology Service of "Hospital das Clínicas" of the University of São Paulo School of Medicine. All the three studied gene exons were amplified by polymerase chain reaction (PCR) and were analyzed by dHPLC, which was the method used for screen mutations. The samples with altered eluting progress were directly sequenced. No 
mutations were found in the VHL gene, only two polymorphisms previously described in the exon 1, c. $-77 \mathrm{C}>\mathrm{T}$ in two patients and c - $195 \mathrm{G}>$ in $58.6 \%$ out of the total alleles of the studied patients. Two polymorphisms previously described (c. 201-36 G>T and c.487 T>C) in the SDHB gene were found in four patients, as well as silent mutation not yet described (c.540 G>A) and a mutation previously described in patients with pheochromocytoma (c. 293 $\mathrm{G}>\mathrm{A}$ ). A particular patient presented the silent mutation c.540 G>A and the polymorphism c.201-36 G>T. In the SDHD gene two polymorpfisms previously described (c.204 C>T and c.315-32 T>C) were found, one in each patient, as well as an allelic variant previously described in the 3' non-coding region whose frequency has never been studied in other populations (c. ${ }^{*} 612$ $\mathrm{C}>\mathrm{T}$ ) and two substitutions never described in the 3' non-coding region (c. ${ }^{*} 799 \mathrm{~T}>\mathrm{C}$ and c. ${ }^{*} 803 \mathrm{~A}>\mathrm{G}$ ). The variants c. ${ }^{*} 612 \mathrm{C}>\mathrm{T}$ and c. ${ }^{*} 799 \mathrm{~T}>\mathrm{C}$ were detected in only one patient each and have not been found in 200 alleles of normal control subjects studied. The variant $c .{ }^{*} 803 A>G$ was found in nine out of 76 alleles from 38 patients (11.8\%) and in five out of 200 alleles from 100 non-affected subjects $(2.5 \%)$, being, then, a polymorphism significantly more frequent among patients with pheochromocytoma or paraganglioma. Among those seven patients with the polymorphism c.*803 $A>G$, three patients heterozygotous for the polymorphism presented a second polymorphism in the SDHD gene and one of those patients also presented a mutation in the SDHB gene. Out of the other four patients, two presented the polymorphism c. ${ }^{*} 803 A>G$ in heterozygosis. This polymorphism occurs in the nucleotide localized in the position -1 immediately 5 ' to the site where the 
pre-mRNA is cleaved for the insertion of the poly $(A)$ tail, which is essencial to the mRNA stability. The substitution of the $A$ to the $G$ probably presents a functional repercussion, because the $A$ in the position -1 is considered as the most efficient nucleotide in the pre-mRNA cleavage promotion, while the $G$ is considered the least efficient one (scale of cleavage efficiency $A>U>C>$ $\mathrm{G})$. Therefore, the possibility of this polymorphism be associated with susceptibility to the development of pheochromocytoma and paraganglioma is not discarded, being possible that other genetic events are necessary to promote tumorigenesis. In conclusion, this study evidenced a low frequency of mutations in the coding regions of the genes $\mathrm{VHL}$ (mutations not detected), SDHB $(5,2 \%)$ and SDHD (mutations not detected) in this series of patients with sporadic pheochromocytomas and paragangliomas, however, a polymorphism significantly more frequent in patients harboring those tumors was found in the 3 ' non-coding region of the SDHD gene and, for its specific characteristics, it can very well be related to the etiopathogenesis of the pheochromocytoma and paraganglioma,

Descriptors: Pheochromocytoma; Paragamglioma; von-ippel Lindau disease; Mutation; Succinato desidrogenase; Hipertension. 
1. INTRODUÇÃO 


\section{Introdução}

As glândulas adrenais são constituídas de medula e córtex, evoluídos respectivamente da neuroderme e mesoderme ${ }^{1}$.A medula preenche a parte mais interna da glândula e é composta principalmente por células cromafins, que sintetizam e secretam catecolaminas. A córtex, parte mais externa, é envolvida por uma cápsula e tem como principal função a produção de esteróides ${ }^{2}$.

A córtex adrenal é dividida em três partes, quais sejam:

- Zona glomerular, produtora de mineralocorticóides, principalmente a aldosterona;

- Zona fasciculada, produtora de glicocorticóides, principalmente o cortisol;

- Zona reticular, produtora de esteróides sexuais.

Estudos recentes em ratos identificaram uma quarta zona, denominada zona intermediária, localizada entre as zonas glomerulosa e fasciculada, provavelmente relacionada à inibição da proliferação e diferenciação dos adrenócitos ${ }^{1}$.

Dentre as doenças que acometem a medula adrenal, a de maior importância clínica é o feocromocitoma ${ }^{2}$. Trata-se de um tumor constituído de células cromafins que ocorre na medula adrenal ou, também, em qualquer paragânglio extra-adrenal (paragangliomas). Os feocromocitomas são secretores de catecolaminas e neuropeptídeos diversos e sua manifestação clínica mais típica é a hipertensão arterial ${ }^{3,4}$. A hipertensão 
arterial é resultado principalmente do aumento da produção e liberação de noradrenalina e adrenalina, que interagem com receptores $\alpha$ e $\beta$ adrenérgicos em várias células, levando ao aumento da contratilidade e freqüência cardíaca e à vasoconstrição ${ }^{2}$. 0 diagnóstico precoce pode levar a cura em até $90 \%$ dos casos, o que evidencia a importância do reconhecimento destes tumores. Outros sintomas incluem dores de cabeça em $80 \%$ dos casos, palpitações em $64 \%$ e sudorese em $57 \%$ dos relatos. Esta tríade presente em pacientes hipertensos confere uma sensibilidade diagnóstica para feocromocitoma de $90,9 \%$ e especificidade de $93,8 \%{ }^{5}$. Outras manifestações tais como, hipercalcemia, síndrome de Cushing, diabetes mellitus, acidose láctica, arritmias cardíacas, cardiomiopatias, edema pulmonar, acidente vascular cerebral, convulsões e outros distúrbios mentais já foram descritos em portadores de feocromocitoma. Alguns pacientes apresentam, ainda, sintomas mínimos ou ausência dos mesmos ${ }^{3}$. O feocromocitoma ocorre em ambos os sexos, tem maior incidência entre a terceira e quarta décadas de vida e é o fator etiológico responsável por $0,05 \%$ a $0,1 \%$ dos casos de hipertensão arterial ${ }^{4}$. O feocromocitoma ocorre em um a dois adultos em 100.000 indivíduos por ano, sugerindo que se $20 \%$ da população adulta for hipertensa, aproximadamente cinco feocromocitomas poderão ser encontrados em 100.000 hipertensos por ano 5

Classicamente, considerava-se que $10 \%$ dos feocromocitomas eram malignos, $10 \%$ bilaterais, $10 \%$ extra-adrenais (dos quais 10\% extraabdominais), $10 \%$ não associados a hipertensão e 10\% hereditários. 
Pesquisas recentes têm modificado este conceito de ser feocromocitoma o "tumor dos 10\%". Em algumas casuísticas, até $30 \%$ dos pacientes são portadores de mutações germinativas em um dos genes que predispõem ao desenvolvimento de feocromocitomas ou paragangliomas e sabe-se que o risco de malignidade do feocromocitoma excede a $10 \%{ }^{6}$. Histologicamente, não é possível diferenciar os tumores malignos dos benignos e o diagnóstico de malignidade é baseado na ocorrência de invasão vascular, ou também, capsular e de estruturas adjacentes ou na presença de metástases em tecidos normalmente desprovidos de células cromafins ${ }^{4}$

Paragangliomas são tumores extra-adrenais que derivam do sistema nervoso parassimpático e simpático ${ }^{7}$. Os paragangliomas associados ao sistema nervoso parassimpático desenvolvem-se na cabeça e no pescoço e são geralmente não funcionantes. Os paragangliomas associados ao sistema nervoso simpático desenvolvem-se na medula adrenal ou em gânglios simpáticos e são geralmente funcionantes, produzindo excesso de catecolaminas. A incidência dos paragangliomas é de um a dois casos em 100.000 indivíduos $^{7}$. Menos de $30 \%$ dos pacientes apresentam excesso de catecolaminas ${ }^{8}$. Aproximadamente $40 \%$ dos casos são familiares e apresentam-se como tumores de crescimento lento e altamente vascularizados ${ }^{9}$. 


\subsection{Síndromes genéticas associadas ao feocromocitoma e ao paraganglioma}

A maioria dos feocromocitomas é de ocorrência esporádica, mas a agregação familial de feocromocitomas e de paragangliomas tem sido repetidamente descrita na literatura. Classicamente, $10 \%$ a $15 \%$ dos casos de feocromocitoma eram atribuídos a causas hereditárias, mas, em algumas séries, um número expressivo dos casos ocorre secundariamente a mutações em algum alelo de susceptibilidade ${ }^{10}$. Várias síndromes genéticas, todas transmitidas de forma autossômica dominante, estão associadas a um risco aumentado para o desenvolvimento de feocromocitoma, incluindo a Neoplasia Endócrina Múltipla (NEM) do tipo 2, a doença de Von-Hippel Lindau, a neurofibromatose tipo 1 e os feocromocitomas e paragangliomas hereditários. Estas síndromes são causadas por mutações nos genes RET, VHL, NF1 e SDHs (SDHD, SDHB e SDHC), respectivamente. A etiologia genética destas síndromes está bem estabelecida, entretanto, elas parecem estar relacionadas a apenas uma parcela dos casos de feocromocitoma familial. Desta forma, outros genes ainda não identificados também devem conferir susceptibilidade ao desenvolvimento do feocromocitoma ${ }^{11}$. Dahia et cols. descreveram recentemente dois novos loci de susceptibilidade para o feocromocitoma no cromossomo 2 (2cen) e no cromossomo 16 (16p13). Os dois loci são necessários para o desenvolvimento da doença e os resultados do estudo sugerem que o locus do cromossomo 2 seja um gene supressor tumoral ${ }^{12}$. 


\subsubsection{Doença de von Hippel Lindau}

O gene VHL é um gene supressor tumoral relativamente pequeno (3 exons) localizado no cromossomo 3p25-26, sendo necessária a inativação dos dois alelos para que ocorra a transformação da célula normal em célula tumoral (Figura 1).

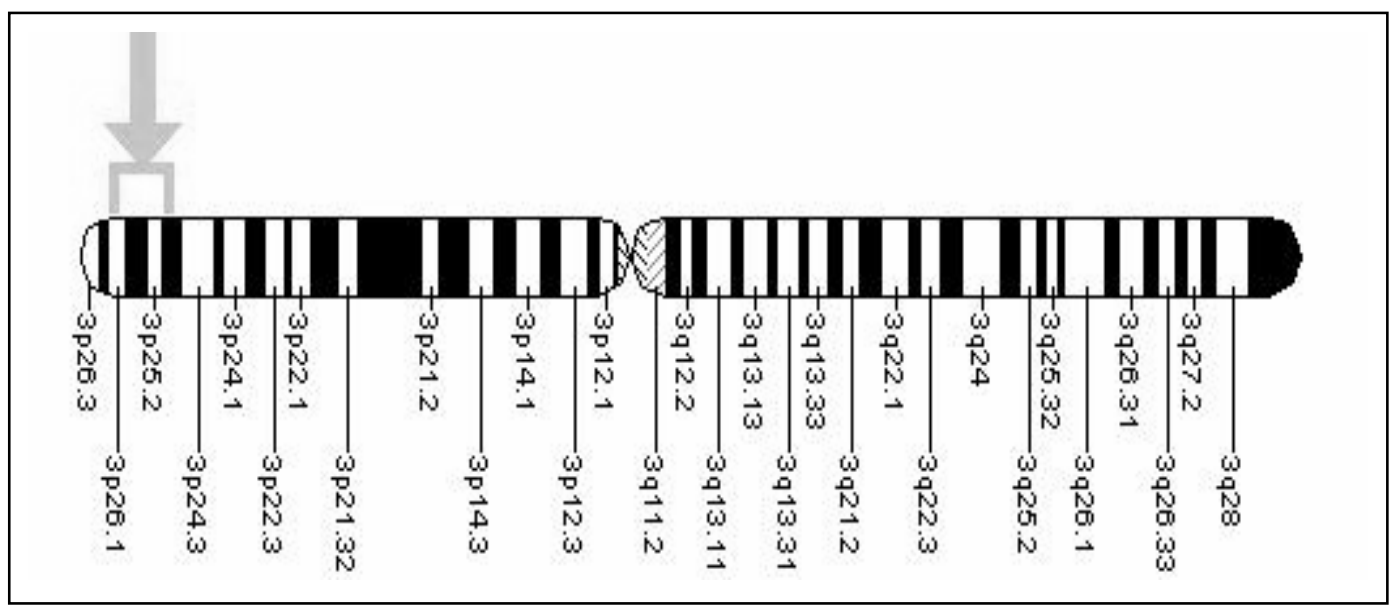

Figura 1: $O$ gene VHL é um gene supressor tumoral, localizado no cromossomo 3p25-26

O gene VHL codifica uma proteína de 213 aminoácidos e uma proteína de 160 aminoácidos, que é produto de um sítio alternativo do início da tradução (metionina presente no códon 54). Os dois produtos gênicos apresentam características bioquímicas e funcionais semelhantes e são expressos de maneira ubíqua em tecidos humanos normais ${ }^{14}$. A doença de Von Hippel-Lindau é uma doença familiar associada ao feocromocitoma, que apresenta uma incidência estimada de 2 a 3 afetados por 100.000 pessoas e ocorre em pacientes com mutações germinativas no gene VHL, predispondo 
ao aparecimento de tumores múltiplos. Entre eles, destacam-se os hemangioblastomas cerebelares, espinais e de retina, feocromocitoma, carcinoma renal e tumores neuroendócrinos pancreáticos. As principais causas de óbito nesta doença são complicações ligadas à evolução dos carcinomas renais e dos hemangioblastomas do sistema nervoso central ${ }^{13}$, 14, 15 . O diagnóstico clínico é feito em pacientes que apresentam pelo menos um tumor típico da doença na presença de história familiar. Em pacientes sem história familiar, o diagnóstico é feito na presença de dois ou mais hemangioblastomas ou um hemangioblastoma e um tumor visceral ${ }^{16}$.

Embora a doença possa ser considerada recessiva ao nível celular, sua herança obedece a um padrão autossômico dominante. Indivíduos heterozigotos para mutações germinativas no gene VHL manifestam doença após a perda do alelo normal (perda da heterozigose) e geralmente apresentam tumores múltiplos e bilaterais, de aparecimento precoce em comparação aos pacientes sem a mutação germinativa, onde os dois alelos precisam ser afetados por eventos somáticos independentes ${ }^{14}$. Mutações germinativas no gene VHL estão presentes em $100 \%$ dos casos de famílias com quadro clínico clássico em mais de um indivíduo afetado. As mutações estão espalhadas nos três exons, já tendo sido descritas mutações missense, nonsense, além de microdeleções, grandes deleções e inserções ${ }^{14}$.

A proteína VHL atua por meio da ligação com a Elongina C, Elongina B e Culina, formando o complexo VCB. Este complexo guia substratos protéicos para a degradação (proteólise) através da ubiquitinização, 
processo no qual o substrato a ser degradado liga-se a ubiquitina e é encaminhado para o proteossoma, onde ocorre a digestão enzimática. Dentre os substratos do complexo VCB está o HIF-1 1 , fator de transcrição hipoxia-induzido que aumenta a expressão de genes que codificam proteínas angiogênicas (fator de crescimento do endotélio vascular - VEGF e fator de crescimento derivado de plaquetas - PDGF- $\beta$ ) e mitogênicas (fator de crescimento transformante - TGF- $\alpha$ ). Em condições normais de oxigenação, ocorre degradação do HIF-1 $\alpha$, no entanto, nas células submetidas à hipoxia, não ocorre degradação apropriada do HIF-1 $\alpha$, que vai estimular a expressão do VEGF e PDGF- $\beta$, com conseqüente formação de novos vasos sanguíneos, na tentativa de regularizar o suprimento tecidual de oxigênio (Figura 2). Na ausência da proteína VHL selvagem, como ocorre na doença de von Hippel-Lindau, o HIF-1 $\alpha$ deixa de ser degradado e seu aumento intracelular estimula a expressão dos genes VEGF e PDGF- $\beta$, o que explica a grande vascularização de alguns dos tumores que aparecem nesta condição ${ }^{13}$. Um mecanismo em potencial para explicar a carcinogênese é a produção aumentada do TGF-a, que pode estimular a expressão de receptores para o fator de crescimento epidérmico (EGF). Uma vez que o TGF- $\alpha$ também exerce efeitos após sua ligação aos receptores de EGF, estabelece-se uma alça mitogênica autócrina. Outros possíveis mecanismos independentes do HIF-1a que podem explicar a tumorigênese incluem anormalidades no ciclo celular e no processamento da fibronectina, observadas em células que não expressam a proteína $\mathrm{VHL}^{13}$. 
O mecanismo pelo qual a ausência da proteína VHL funcionante predispõe ao desenvolvimento do feocromocitoma ainda não está completamente estabelecido. Os feocromocitomas, ao contrário dos hemangioblastomas e dos carcinomas renais de células claras, não são tumores altamente vascularizados, e sugere-se que mutações em heterozigose no gene $\mathrm{VHL}$ possam levar ao desenvolvimento do feocromocitoma por promoverem ganho de função ou por causarem efeito dominante negativo, com a proteína codificada pelo alelo mutado interferindo negativamente na proteína selvagem, codificada pelo alelo não mutado ${ }^{13}$.

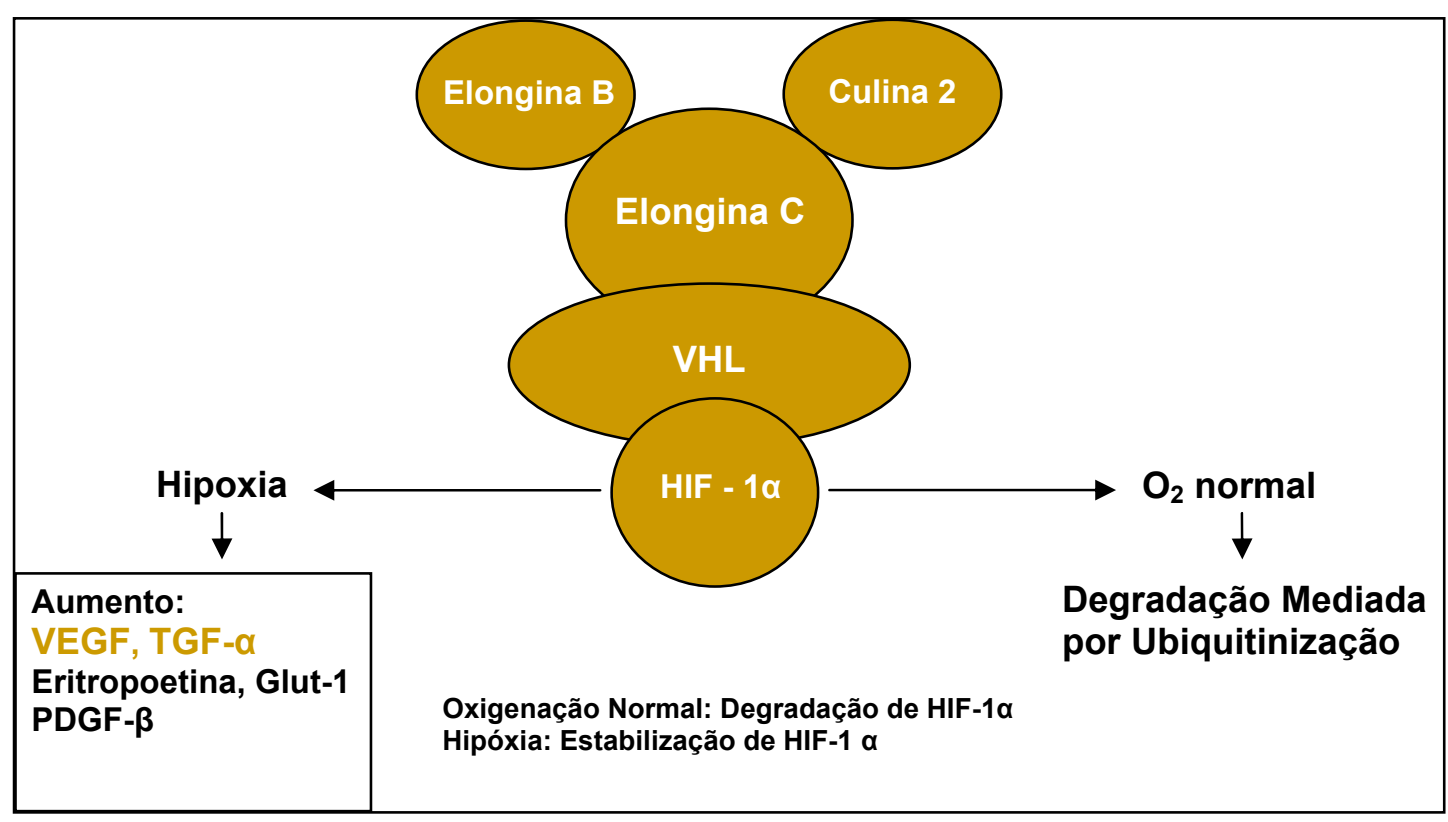

Figura 2: Interação da proteína VHL com outras proteínas. A proteína VHL interage com a Elongina $\mathrm{B}$, Elongina $\mathrm{C}$ e Culina 2 para formar o complexo VCB-CUL2, que em condições de oxigenação normal, guia substratos, como o HIF-1 $\alpha$, para degradação. Adaptado de: Lonser RR, Glenn GM, et al. The Lancet. 2003; 2059-67. 


\subsubsection{Mutações nos genes do complexo II mitocondrial (Succinato- desidrogenase)}

Succinato desidrogenase é um complexo enzimático mitocondrial que desempenha papel fundamental na fosforilação oxidativa. Os genes SDHD e SDHB fazem parte do complexo mitocondrial II e, juntamente com as subunidades SDHA e SDHC, formam a cadeia aeróbica de transporte de elétrons, desempenhando um papel fundamental na percepção dos níveis de oxigênio celular. Mutações nas quatro subunidades deste complexo já foram reportadas. O gene SDHA pertence à parte catalítica hidrofóbica do complexo e defeitos nesta subunidade foram descritos como causa de ataxia, atrofia óptica e encefalopatia associada à diminuição da glicose cerebroespinhal juntamente com acidose láctica. Defeitos no gene SDHA causam, assim, desordens metabólicas decorrentes de anormalidades no ciclo de Krebs. Mutações nos genes SDHB, SDHC e SDHD estão associadas a fenótipos completamente diferentes dos causados por mutações no gene SDHA ${ }^{18}$.

O gene SDHB está localizado no cromossomo 1p36 (Figura 3) e consiste de 8 exons. O gene SDHD consiste de 4 exons e está localizado no cromossomo 11q23 (Figura 4).

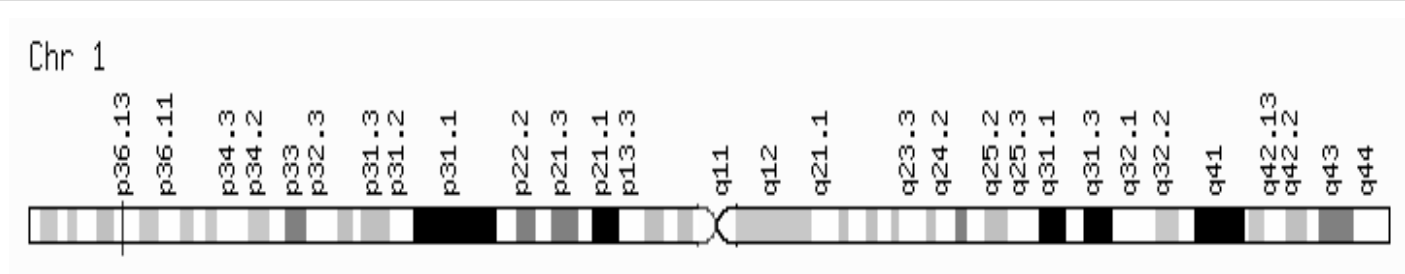

Figura 3: Localização do gene SDHB 


\section{Chr 11

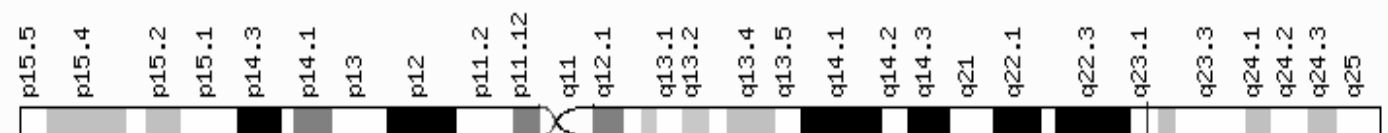

Figura 4: Localização do gene SDHD

Mutações nestas duas subunidades estão relacionadas à presença de paragangliomas, que tipicamente são tumores altamente vascularizados. Existem evidências de que a tumorigênese dos paragangliomas esteja associada com a perda de heterozigose, conseqüente perda completa da atividade de SDH e ativação de mecanismos relacionados com a hipóxia ${ }^{17}$, uma vez que o complexo II mitocondrial tem papel importante na sinalização e percepção dos níveis de oxigênio celular. A perda da função do complexo II mitocondrial deve ser percebida pela célula como uma situação de hipóxia constante, ocasionando intensa angiogênese ${ }^{18}$.

Alguns mecanismos foram propostos para explicar a tumorigênese associada a mutações no complexo SDH, tais como: (1) aumento da meiavida do HIF-1a; (2) acúmulo de espécies reativas de oxigênio intracelular, levando a um aumento do stress oxidativo ou, também, aumento da ocorrência de mutações; (3) mecânismos apoptóticos resultantes da disfunção mitocondrial primária. A hipótese da ativação de mecanismos induzidos por hipóxia ocasionarem a tumorigênese é a mais aceitável, por analogia com os mecanismos relacionados à inativação do gene VHL, que resulta em diminuição da degradação do HIF-1a, com conseqüente transcrição de genes que codificam proteínas angiogênicas, tais como o 
VEGF. Os resultados de Pollard et al, demonstram que mutações bialélicas no gene SDHB ocasionam aumento de succinato e ainda mutações neste

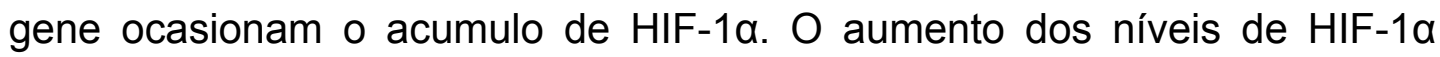
resultam no aumento da expressão de genes alvo de HIF-1a, como o VEGF e na angiogênese. Os resultados demosntraram ainda que o aumento de succinato leva ao aumento de HIF-1a in vivo, o que antes já estava demosntrado in vitro ${ }^{19}$.

Mutações nos genes SDHB, SDHC e SDHD são reconhecidamente responsáveis pela maioria dos paragangliomas familiares, que correspondem a $40 \%-50 \%$ dos casos de paragangliomas ${ }^{20}$, e também por uma fração significativa dos paragangliomas e feocromocitomas não familiares ${ }^{21}$.

Mutações no gene SDHD têm sido identificadas em famílias portadoras de paragangliomas multifocais, principalmente de cabeça e pescoço, bem como feocromocitomas. A penetrância das mutações do gene SDHD depende da herança ser paterna ou materna. A doença não se manifesta quando herdada da mãe, mas tem alta penetrância quando herdada do pai. Este fenômeno poderia estar associado ao imprinting do alelo materno, porém, devido à expressão bialélica do SDHD ter sido relatada em vários tecidos, outros mecanismos têm sido aventados para explicar a manifestação restrita à transmissão do alelo paterno ${ }^{22}$. Portadores de mutações no gene SDHD estão mais predispostos ao aparecimento de paragangliomas multifocais ${ }^{23}$. 
Mutações no gene SDHB são relacionadas com o desenvolvimento de paragangliomas de abdome, pelve e tórax, contudo paragangliomas de cabeça e pescoço e feocromocitomas também já foram observados. Portadores de mutações neste gene estão altamente predispostos ao desenvolvimento de paragangliomas malignos, carcinoma renal e carcinoma papilífero de tireóide ${ }^{24}$.

\subsubsection{RET}

O proto-oncogene RET está localizado no cromossomo 10q11.2 e contém 21 exons. Seis regiões são consideradas "hot spots", pois albergam mutações que respondem por $97 \%$ dos casos de NEM $2^{25}$. O proto-ocogene RET codifica um receptor transmembrana tirosino-quinase e é expresso em células derivadas da crista neural ${ }^{26}$. A NEM 2 é dividida em diferentes variantes clínicas:

- NEM 2A - caracterizada por carcinoma medular de tireóide em 90\% dos casos, feocromocitoma em $50 \%$ dos casos e hiperplasia da glândula paratireóide em $20 \%$ - 30\% dos casos.

- NEM 2B - caracterizada por carcinoma medular de tireóide, feocromocitoma, hábito marfanóide e ganglioneuromatose intestinal e de mucosas.

Feocromocitomas associados a NEM 2A são diagnosticados com maior freqüência entre os 30 e 40 anos de vida ${ }^{27}$. 


\subsubsection{NF1}

O gene NF1 é um gene supressor tumoral localizado no cromossomo 17q11.2 constituído por 60 exons. Este gene, considerado um gene supressor tumoral, codifica a neurofibrina, proteína que possui similaridade com a família das GTPases ativadoras de proteínas. A neurofibrina funciona como um regulador negativo de Ras, acelerando a conversão de Ras-GTP para Ras-GDP ${ }^{28}$.

A Neurofibromatose tipo 1 (NF1), também conhecida como doença de Recklinghausen, representa a doença familiar mais comum que predispõe ao desenvolvimento de tumores no sistema nervoso periférico. Trata-se de uma desordem genética autossômica dominante que ocorre em 1 a cada 3.000 - 4.000 indivíduos. Freqüentemente, mutações no gene NF1 predispõem a neurofibromas nodulares e plexiformes, tumores intestinais, gliomas malignos e leucemia mielóide crônica juvenil. Para pacientes com neurofibromatose, o risco de desenvolver tumores malignos ou benignos é de aproximadamente quatro vezes mais do que a população geral. A prevalência estimada de feocromocitoma associada à neurofibromatose é de $0,1 \%$ a $5,7 \%$. Esta prevalência pode variar, no entanto de $20 \%$ a $50 \%$ nos pacientes portadores de neurofibromatose com hipertensão. Em estudos de autópsias de pacientes com NF1, a prevalência de feocromocitoma variou de $3,3 \%$ a $13 \%^{28}$. 


\subsection{Estudos Genéticos em Feocromocitomas Esporádicos}

Apesar de mutações no gene VHL terem sido inicialmente descritas em portadores da doença de von Hippel-Lindau, um recente estudo realizado em pacientes portadores de feocromocitoma (241 pacientes), feocromocitoma e paraganglioma (8 pacientes) e paraganglioma esporádicos (22 pacientes) demonstrou a presença de mutações germinativas no gene VHL em 30 pacientes (11\% dos casos). Também foram detectadas mutações germinativas nos genes RET (5\% dos pacientes), SDHD (4\% dos pacientes) e SDHB (4\% dos pacientes) (Gráfico1).

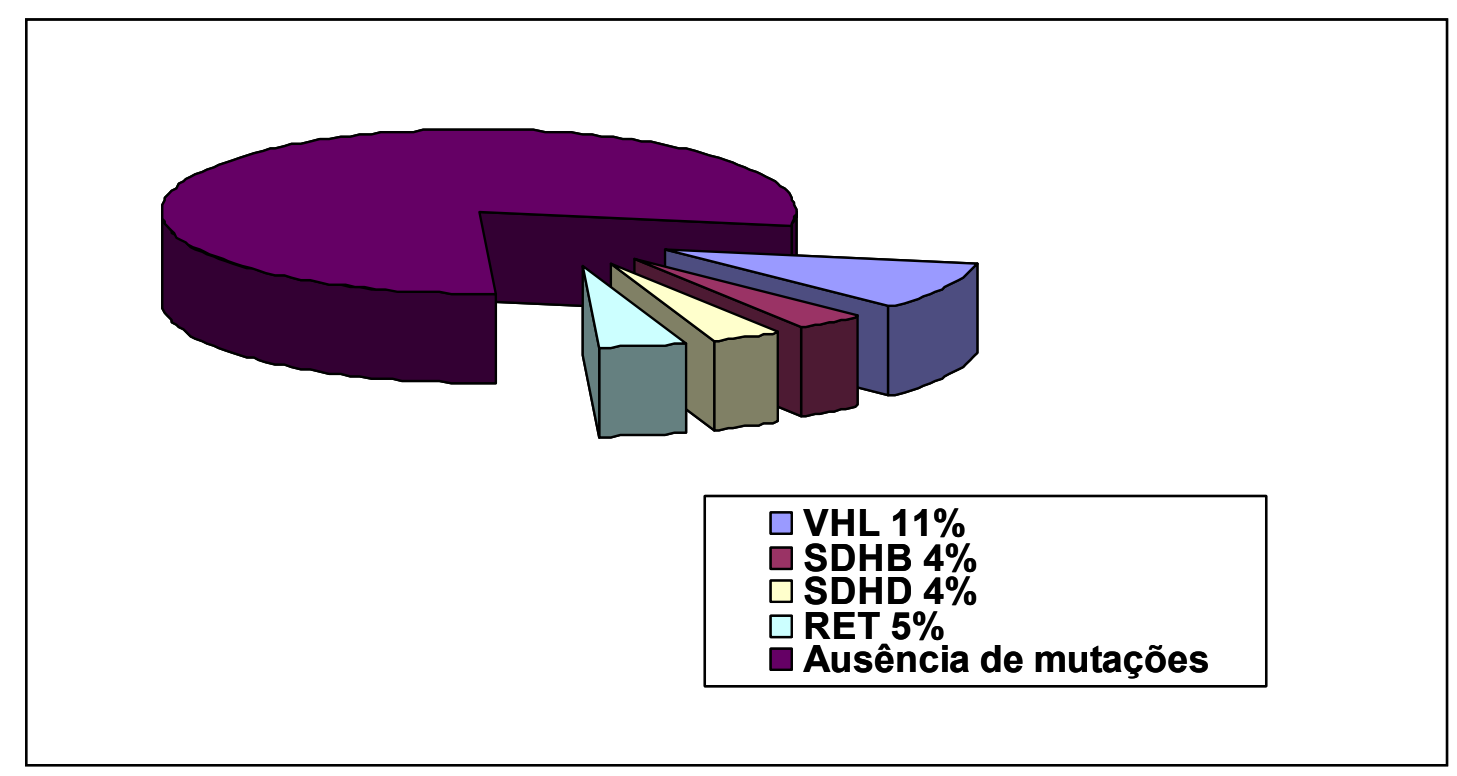

Gráfico 1: Gráfico representativo dos resultados obtidos por Neumann et al, 2002. Duzentos e setenta e um pacientes portadores de feocromocitoma ou também, paraganglioma foram rastreados para mutações nos genes VHL, SDHB, SDHD e RET: $11 \%$ apresentaram mutações no gene VHL, $4 \%$ no gene SDHB, $4 \%$ no gene SDHD e $5 \%$ no gene RET. 
A idade de aparecimento dos sintomas foi significativamente menor nos portadores de mutações em relação aos que não apresentavam mutações. Mutações no gene VHL estavam presentes em $42 \%$ dos pacientes que apresentaram os sintomas em idade inferior a 18 anos. $\mathrm{Na}$ apresentação do quadro, $68 \%$ dos portadores de mutações apresentavam apenas um tumor e feocromocitomas múltiplos foram estatisticamente mais freqüentes entre os pacientes com mutações. Dentre os 30 pacientes com mutações no gene VHL, cinco desenvolveram outras características da síndrome de von Hippel-Lindau durante o seguimento. Além disso, durante o seguimento, 12 portadores de mutações no gene VHL apresentaram relatos de familiares com história positiva para a doença. Em quatro pacientes com mutações no gene VHL, o DNA dos pais estava disponível e o rastreamento não demonstrou a presença das mutações, evidenciando, nestes quatro casos, mutações germinativas espontâneas ${ }^{29}$.

Um estudo recente rastreou 314 pacientes com feocromocitoma ou paraganglioma. Dentre eles, 258 apresentavam a forma esporádica da doença. Dezoito pacientes apresentaram mutações no gene SDHB $(7 \%)$, nove pacientes apresentaram mutações no gene $\mathrm{VHL}(3,5 \%)$, dois no gene $\operatorname{SDHD}(0,8 \%)$, e um paciente apresentou mutação no gene RET $(0,4 \%)$ (Gráfico 2). Entre 52 pacientes com tumores malignos, 18 possuíam mutações e 15 delas estavam localizadas no gene SDHB. Estes tumores eram significantemente maiores dos que os tumores não associados a mutações. Dentre as mutações no gene SDHD, a grande maioria foi encontrada em pacientes com histórico familiar (11\%) e em portadores de 
paragangliomas. Dentre estes pacientes, $81,8 \%$ tinham histórico familiar paterno. Não foram encontradas mutações no gene SDHC ${ }^{30}$.

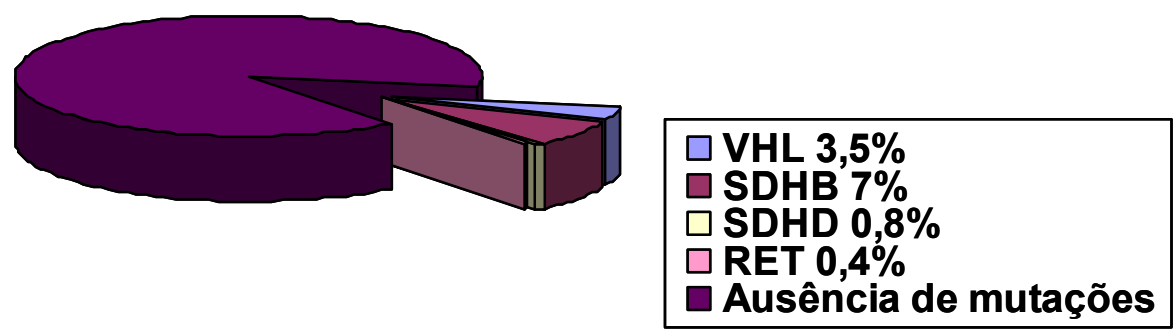

Gráfico 2: Gráfico representativo dos resultados obtidos por Amar et al., 2005. Rastreamento de mutações nos genes VHL, SDHB, SDHD, SDHC e RET em 258 casos de feocromocitoma ou paraganglioma aparentemente esporádicos. O gene VHL apresentou mutações em 3,5\% dos casos, o gene SDHB em $7 \%$, SDHD em $0,8 \%$ dos casos e o gene RET em $0,4 \%$. Não foram encontradas mutações no gene SDHC.

Um estudo publicado em 2003 rastreou mutações nos genes VHL, SDHB e SDHD em 84 pacientes com tumores esporádicos, observando que $2,7 \%$ dos pacientes apresentaram mutações no gene $\mathrm{VHL}, 8 \%$ apresentaram mutações no gene SHDB e 7\% no gene SDHD. Trinta e três tumores estavam disponíveis para análise molecular, ensaios enzimáticos e imunohistoquímicos. A perda de heterozigose foi um achado presente em todos os tumores com mutações no gene SHDB disponíveis. Foram realizados ensaios enzimáticos nestes mesmos tumores e a inativação da atividade catalítica do complexo II mitocondrial foi evidenciada (interrupção 
do ciclo de Kreb's). O estudo histológico demonstrou, ainda, evidências de malignidade. Este estudo sugere que o gene SDHB seja um gene supressor tumoral e que mutações neste gene estejam associadas a um alto risco de malignidade e recorrência ${ }^{17}$.

Um rastreamento em 57 pacientes portadores de paraganglioma originado no sistema nervoso parassimpático, sendo 19 familiares e 38 aparentemente esporádicos, encontrou mutações no gene SDHD em 32 dos 57 pacientes (56\%), incluindo 19 dos 19 casos de paraganglioma familiar e 13 dos 38 pacientes aparentemente esporádicos (34\%). Estes resultados demonstram um número expressivo de mutações no gene SDHD em pacientes portadores de paragangliomas de origem parassimpática aparentemente esporádicos ${ }^{9}$.

Devido ao potencial maligno dos tumores associados a mutações no gene SDHB e à natureza heterogênea da doença de von Hippel-Lindau, que pode cursar com tumores múltiplos em diversos órgãos, o teste genético tem sido recomendado para portadores de feocromocitomas e paragangliomas esporádicos ${ }^{30}$, por permitir um seguimento mais cuidadoso dos pacientes portadores de mutações no gene SDHB, o diagnóstico precoce de outros tumores associados à doença de von Hippel-Lindau, bem como o rastreamento familiar. 
2. OBJETIVOS 


\section{Objetivos}

Realizar o rastreamento de mutações nos genes VHL, SDHB e SDHD em pacientes portadores de feocromocitoma ou, também, paraganglioma esporádicos acompanhados no Serviço de Endocrinologia do Hospital das Clínicas da Faculdade de Medicina da Universidade de São Paulo com o objetivo de verificar a freqüência destas mutações entre os pacientes acompanhados neste Serviço. 
3. CASUÍSTICA, MATERIAIS E MÉTODOS 


\section{Casuística, materiais e métodos}

\subsection{Casuística}

Todos os exons dos genes VHL, SDHB e SDHD foram estudados em 38 pacientes portadores de feocromocitoma ou também, paraganglioma esporádicos acompanhados no Serviço de Endocrinologia do HC-FMUSP. Catorze pacientes $(36,8 \%)$ eram do sexo masculino e $24(63,2 \%)$ do sexo feminino. Trinta e um pacientes eram portadores de feocromocitoma unilateral, um portador de feocromocitoma bilateral. Cinco pacientes eram portadores de paragangliomas abdominais e um paciente portador de feocromocitoma maligno e paraganglioma abdominal. Dentre os 38 portadores de feocromocitoma, cinco (14,3\%) apresentavam a forma maligna da doença. A idade ao diagnóstico estava disponível em 35 pacientes, e variou de 7 a 75 anos, média de 34,4 anos: $8,6 \%$ dos pacientes estavam na primeira década de vida, $37,1 \%$ dos pacientes estavam entre a segunda e terceira decádas de vida, $37,1 \%$ entre a quarta e quinta décadas e $17,2 \%$ entre a sexta e a oitava décadas de vida. Apenas três dos pacientes relataram histórico familiar para a doença (pacientes números 15, 37 e 38). Esta informação não estava disponível para dois pacientes e os outros negaram familiares portadores de feocromocitoma ou paraganglioma. As características demográficas, clínicas e anátomo-patológicas dos pacientes estão demonstradas na Tabela 1. 
Seis indivíduos controles não portadores de feocromocitoma ou paraganglioma foram selecionados para a realização da técnica de cromatografia liquída denaturante de alta performance (dHPLC) e que somados a mais 94 controles normais, escolhidos randomicamente serviram de base para o estudo das variações alélicas encontradas nos pacientes e nunca antes descritas na literatura, como uma forma de estabelecer se seriam mutações ou apenas polimorfismos presentes em nossa população. Esses 100 controles não eram portadores de feocromocitoma ou paraganglioma, $80 \%$ eram do sexo feminino e a idade média era de 28 anos, variando de 17 a 44 anos. . 
Tabela 1. Dados demográficos dos pacientes, apresentação clínica e classificação histológica dos tumores estudados.

\begin{tabular}{|c|c|c|c|c|c|c|}
\hline Pacientes & Gênero & $\begin{array}{c}\text { Idade } \\
\text { atual } \\
\text { (anos) }\end{array}$ & $\begin{array}{l}\text { I. D. } \\
\text { (anos) }\end{array}$ & H. F. & $\begin{array}{l}\text { Apresentação } \\
\text { clínica }\end{array}$ & $\begin{array}{l}\text { Classificação } \\
\text { histológica }\end{array}$ \\
\hline 1 & $\mathrm{~F}$ & 33 & 23 & - & Feocromocitoma & Benigno \\
\hline 2 & $\mathrm{~F}$ & 47 & 41 & - & Feocromocitoma & Benigno \\
\hline 3 & $\mathrm{~F}$ & 63 & 60 & - & Feocromocitoma & Benigno \\
\hline 4 & $\mathrm{~F}$ & 46 & 41 & - & Feocromocitoma & Benigno \\
\hline 5 & $\mathrm{~F}$ & 49 & 41 & - & Feocromocitoma & Benigno \\
\hline 6 & $\mathrm{~F}$ & 32 & 18 & - & Paraganglioma & Benigno \\
\hline 7 & $\mathrm{M}$ & 29 & 24 & - & Feocromocitoma & Benigno \\
\hline 8 & $\mathrm{M}$ & 54 & 42 & - & Feocromocitoma & Benigno \\
\hline 9 & $\mathrm{~F}$ & 69 & 65 & - & Feocromocitoma & Benigno \\
\hline 10 & $\mathrm{~F}$ & 25 & 20 & - & Feocromocitoma & Benigno \\
\hline 11 & $\mathrm{~F}$ & 46 & 38 & - & Paraganglioma & Benigno \\
\hline 12 & $M$ & 52 & 50 & - & Feocromocitoma & Benigno \\
\hline 13 & $\mathrm{~F}$ & 24 & 9 & - & Feocromocitoma & Maligno \\
\hline 14 & $\mathrm{~F}$ & 42 & 29 & - & Paraganglioma & Benigno \\
\hline 15 & $\mathrm{~F}$ & 30 & 28 & + & Feocromocitoma & Benigno \\
\hline 16 & $M$ & 27 & 25 & - & $\begin{array}{c}\text { Feocromocitoma e } \\
\text { Paraganglioma }\end{array}$ & Malignos \\
\hline 17 & $\mathrm{~F}$ & 58 & ND & - & Feocromocitoma & Benigno \\
\hline 18 & $\mathrm{M}$ & 46 & 32 & - & Feocromocitoma & Benigno \\
\hline 19 & $M$ & 14 & 13 & ND & Feocromocitoma & Benigno \\
\hline 20 & $M$ & 53 & 51 & ND & Feocromocitoma & Benigno \\
\hline 21 & $M$ & 54 & 40 & - & Feocromocitoma & Maligno \\
\hline 22 & $\mathrm{~F}$ & 81 & 79 & - & Feocromocitoma & Benigno \\
\hline 23 & $\mathrm{~F}$ & 42 & 37 & - & Feocromocitoma & Benigno \\
\hline 24 & $\mathrm{M}$ & 21 & 15 & - & Feocromocitoma & Benigno \\
\hline 25 & $\mathrm{~F}$ & 36 & 31 & - & Feocromocitoma & Benigno \\
\hline 26 & $\mathrm{~F}$ & 46 & 45 & - & Feocromocitoma & Benigno \\
\hline 27 & $M$ & 17 & ND & - & Feocromocitoma & Benigno \\
\hline 28 & $\mathrm{~F}$ & 85 & 75 & - & Feocromocitoma & Benigno \\
\hline 29 & $\mathrm{~F}$ & 40 & 21 & - & Feocromocitoma & Maligno \\
\hline 30 & $\mathrm{~F}$ & 67 & 63 & - & Feocromocitoma & Benigno \\
\hline 31 & $\mathrm{M}$ & 25 & 14 & - & Feocromocitoma & Benigno \\
\hline 32 & $\mathrm{~F}$ & 50 & 49 & - & Feocromocitoma & Benigno \\
\hline 33 & $\mathrm{~F}$ & 31 & 24 & - & Feocromocitoma & Maligno \\
\hline 34 & $M$ & 32 & 31 & - & Paraganglioma & Benigno \\
\hline 35 & $\mathrm{~F}$ & 19 & 19 & - & Paraganglioma & Benigno \\
\hline 36 & $\mathrm{~F}$ & & ND & - & Feocromocitoma & Benigno \\
\hline 37 & $M$ & & 7 & - & Feocromocitoma & Benigno \\
\hline 38 & $\mathrm{M}$ & & 7 & + & $\begin{array}{c}\text { Feocromocitoma } \\
\text { bilateral }\end{array}$ & Benignos \\
\hline
\end{tabular}

I.D.: Idade ao diagnóstico H. F.: Histórico Familiar

ND: Não disponível 


\subsection{Materiais e métodos}

Após a obtenção do Termo de Consentimento Pós-Informado, foram colhidos $5,0 \mathrm{~mL}$ de sangue periférico de cada um dos pacientes para extração de DNA genômico de leucócitos.

\subsubsection{Extração de DNA genômico a partir de leucócitos de sangue periférico}

Em um tubo graduado, foram acrescentados $15 \mathrm{~mL}$ de tampão Tris EDTA (TE) para cada $5 \mathrm{~mL}$ de sangue total. $\mathrm{O}$ tubo foi homogenizado manualmente e, a seguir, centrifugado a $2.800 \mathrm{rpm}$ durante $5 \mathrm{~min}$. $\mathrm{O}$ sobrenadante foi desprezado e o pellet formado, lavado em $15 \mathrm{~mL}$ de TE até sua dissolução total.

Após a lavagem, foi realizada nova centrifugação e o sobrenadante foi desprezado. Esta lavagem foi repetida quatro vezes, até que o pellet adquirisse coloração esbranquiçada. Em seguida, foram adicionados ao pellet:

- $\quad 3 \mathrm{~mL}$ de solução de lise de glóbulos brancos ( $\mathrm{NaCl} 150 \mathrm{mM}$; Tris-HCl 10 mM pH 8,0; EDTA 10 mM)

- $\quad 200 \mu \mathrm{L}$ de sódio dodecil sulfato (SDS) $10 \%$;

- $\quad 100 \mu \mathrm{L}$ de Proteinase $\mathrm{K} 10 \mathrm{mg} / \mathrm{mL}$ 
Esta solução foi incubada por 12 horas a $37^{\circ} \mathrm{C}$ e, após este intervalo, foi adicionado $1 \mathrm{~mL}$ de $\mathrm{NaCl}$ 5M. Após agitação vigorosa durante $30 \mathrm{~min}$, o tubo foi centrifugado a $3.700 \mathrm{rpm}$ durante $15 \mathrm{~min}$, o pellet desprezado e o sobrenadante recolhido em novo tubo.

Foram adicionados $10 \mathrm{~mL}$ de etanol absoluto gelado e realizada homogenização por inversão até o aparecimento de um precipitado fibrilar que foi transferido para novo tubo tipo eppendorff de 1,5 $\mathrm{mL}$ e seco em temperatura ambiente durante $30 \mathrm{~min}$. O pellet foi ressuspendido em 50 $200 \mu \mathrm{L}$ de $\mathrm{H}_{2} \mathrm{O}$ miliQ estéril e incubado a $37^{\circ} \mathrm{C}$ durante $15 \mathrm{~min}$. O DNA assim obtido foi quantificado, diluído para uma concentração de $300 \mathrm{ng} / \mu \mathrm{L}$ e armazenado à temperatura de $-20^{\circ} \mathrm{C}$.

\subsubsection{Reação em Cadeia da Polimerase (PCR)}

Todos os exons dos genes VHL, SDHB e SDHD foram amplificados pela técnica de PCR. Iniciadores intrônicos para amplificação dos exons de cada um dos três genes foram desenhados com a utilização do programa primer 3, disponível on line pela página: http://frodo.wi.mit.edu/cgibin/primer3/primer3 www.cgi

O volume total da reação de PCR foi de $50 \mu \mathrm{L}$, consistindo de: 300 $\mathrm{ng} / \mu \mathrm{L}$ de DNA, $0,75 \mu \mathrm{M}$ de cada um dos iniciadores forward e reverse, 0,2 mM de cada um dos desoxinucleotídeos (dATP, dCTP, dGTP, dTTP), 2U de Taq polimerase e tampão da enzima $1 X$ com $1,5 \mathrm{mM}$ de $\mathrm{MgCl}_{2}$. A reação de PCR foi realizada no termociclador da Perkin Elmer Cetus (Perkin Elmer, 
EUA). As temperaturas de amplificação foram estabelecidas por meio de uma curva de aferição. Oito microlitros do produto de cada reação de PCR foram submetidos à eletroforese em gel de agarose $1,2 \%$ com brometo de etídeo a $100 \mathrm{~V}$ por aproximadamente $30 \mathrm{~min}$ e as bandas foram visualizadas com luz ultravioleta (GelDoc 1000 Video Gel Documentation System, BioRad Laboratories, EUA).

\section{A) Gene VHL}

O Exon 1 do gene VHL foi dividido em duas partes, com a construção de dois pares de iniciadores intrônicos para a análise de todo o exon. Os amplicons obtidos com a utilização destes iniciadores foram identificados como VHL 1A e VHL 1B. A seqüência dos iniciadores intrônicos para amplificação dos três exons do gene VHL, com as respectivas temperaturas de anelamento e números de pares de base dos fragmentos amplificados são demonstrados na Tabela 2. Os iniciadores desenhados para o estudo do exon 3 amplificaram apenas a região codificante do gene. 
Tabela 2. Iniciadores utilizados para a amplificação dos exons do gene VHL e respectivas temperaturas de anelamento e números de pares de base dos fragmentos amplificados.

\begin{tabular}{|c|c|c|c|}
\hline$\overline{\text { Gene }}$ & Iniciadores & $\begin{array}{l}\text { Fragmento } \\
\text { amplificado } \\
\text { (pb) }\end{array}$ & $\begin{array}{c}\text { Temperatura } \\
\text { de anelamento } \\
\left({ }^{\circ} \mathrm{C}\right)\end{array}$ \\
\hline \multirow[t]{5}{*}{$\underline{\mathrm{VHL}}$} & & & \\
\hline & $\begin{array}{r}\text { Exon1A - Foward }{ }^{5^{\prime} 3^{\prime}} \text { acagtaacgagttggcctag } \\
\text { Reverse }{ }^{53^{\prime}} \text { ctgcgtgcgegctcccgagt }\end{array}$ & 167 & 60 \\
\hline & $\begin{array}{c}\text { Exon1B - Foward }{ }^{5^{\prime} 3^{\prime}} \text { cgagcgcgcgcgaagactac } \\
\text { Reverse }{ }^{5^{\prime} 3^{\prime}} \text { gaccgtgctatcgtccctgc }\end{array}$ & 503 & 65 \\
\hline & $\begin{array}{c}\text { Exon 2- Foward }{ }^{53^{\prime}} \text { cggtgtggctctttaacaacc } \\
\text { Reverse }{ }^{53^{\prime}} \text { caagtggtctacctgtctt }\end{array}$ & 224 & 58 \\
\hline & $\begin{array}{l}\text { Exon 3- Foward }{ }^{5^{\prime} 3} \mathrm{ttccttgtactgagacctagt} \\
\text { Reverse }{ }^{5^{\prime} 3^{\prime}} \text { tcatcagtaccatcaaaagctga }\end{array}$ & 288 & 57 \\
\hline
\end{tabular}




\section{B) Gene SDHB}

A seqüência dos iniciadores intrônicos para amplificação de cada um dos oito exons do gene SDHB com as respectivas temperaturas de anelamento e números de pares de base dos fragmentos amplificados são demonstrados na Tabela 3. Os iniciadores desenhados para o estudo do exon 8 amplificaram não apenas a região codificante, como também a região 3' não codificante até aproximadamente 40 nucleotídeos localizados 3' ao local correspondente ao sinal de poliadenilação do mRNA. 
Tabela 3. Iniciadores utilizados para a amplificação dos exons do gene SDHB e respectivas temperaturas de anelamento e números de pares de base dos fragmentos amplificados.

\begin{tabular}{|c|c|c|c|}
\hline Gene & Iniciadores & $\begin{array}{l}\text { Fragmento } \\
\text { amplificado } \\
\text { (pb) }\end{array}$ & $\begin{array}{c}\text { Temperatura de } \\
\text { anelamento } \\
\left({ }^{\circ} \mathrm{C}\right)\end{array}$ \\
\hline \multicolumn{4}{|c|}{ er } \\
\hline & $\begin{array}{r}\text { Exon 1- Foward }{ }^{5^{\prime} 3^{\prime}} \text { cccacccgggaaaccggaa } \\
\text { Reverse }{ }^{5^{\prime} 3^{\prime}} \text { cctctctgaggetccaggact }\end{array}$ & 250 & 55 \\
\hline & $\begin{array}{r}\text { Exon 2- Foward }{ }^{5^{\prime} 3^{\prime}} \text { cagcgttacatctgttgtgccag } \\
\text { Reverse }{ }^{5^{\prime} 3^{\prime}} \text { gctggctttcacagagatactca } \\
\end{array}$ & 239 & 62 \\
\hline & 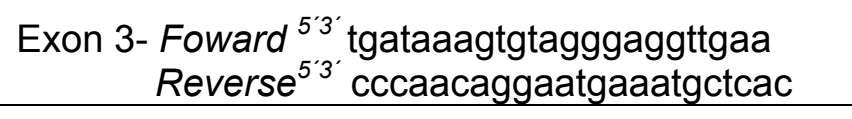 & 169 & 55 \\
\hline & $\begin{array}{r}\text { Exon 4- Foward }{ }^{53^{\prime}} \text { ggatgtgttaaatgtgtgtctcttt } \\
\text { Reverse }{ }^{53^{\prime}} \text { aaccagagagatgcagaaactca }\end{array}$ & 189 & 55 \\
\hline & $\begin{array}{l}\text { Exon 5- Foward }{ }^{5^{\prime} 3^{\prime}} \text { tcttcttcctcttaaccacag } \\
\text { Reverse }{ }^{5^{3}} \text { gaaacaataaatagggactaatgac }\end{array}$ & 163 & 55 \\
\hline & $\begin{array}{l}\text { Exon 6- Foward }{ }^{5^{\prime} 3^{\prime}} \text { caagctcctgcctctct } \\
\text { Reverse }{ }^{5^{\prime} 3^{\prime}} \text { ctcttaaagcaattaaggagcac } \\
\end{array}$ & 162 & 55 \\
\hline & $\begin{array}{c}\text { Exon 7- Foward }{ }^{5^{\prime} 3^{\prime}} \text { gctcagctaatcatccctggttt } \\
\text { Reverse }{ }^{5^{\prime} 3^{\prime}} \text { gctgagggtcaccagccc }\end{array}$ & 176 & 62 \\
\hline & 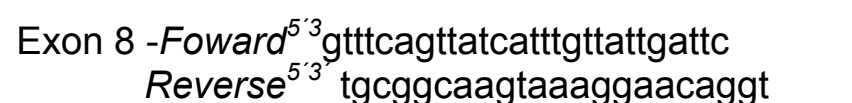 & 305 & 55 \\
\hline
\end{tabular}




\section{C) Gene SDHD}

A seqüência dos iniciadores intrônicos para amplificação de cada um dos quatro exons do gene SDHD com as respectivas temperaturas de anelamento e número de pares de bases dos fragmentos amplificados são demonstrados na Tabela 4. O exon 4 e a região 3' não codificante do gene SDHD foram divididos em três partes, com a construção de três pares de iniciadores para a análise de toda essa região. Os amplicons resulltantes da amplificação com estes pares de iniciadores foram respectivamente nomeados de SDHD 4A, SDHD 4B e SDHD 4C. Os iniciadores desenhados amplificaram não apenas a região codificante, como também a região 3' não codificante até aproximadamente 50 nucleotídeos localizados 3' ao local correspondente ao sítio de clivagem do mRNA para a adição da cauda Poli(A). 
Tabela 4. Iniciadores utilizados para a amplificação dos exons do gene SDHD e respectivas temperaturas de anelamento e números de pares de base dos fragmentos amplificados.

\begin{tabular}{|c|c|c|c|}
\hline Gene & Iniciadores & $\begin{array}{l}\text { Fragmento } \\
\text { amplificado } \\
\text { (pb) }\end{array}$ & $\begin{array}{c}\text { Temperatura } \\
\text { de } \\
\text { anelamento } \\
\left({ }^{\circ} \mathrm{C}\right) \\
\end{array}$ \\
\hline \multirow[t]{6}{*}{$\underline{\text { SDHD }}$} & 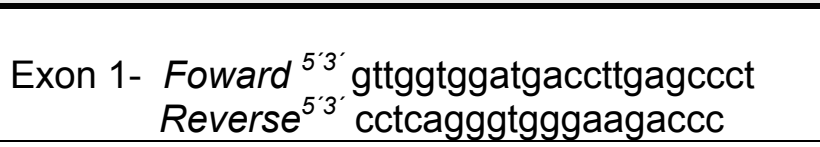 & 109 & 59 \\
\hline & $\begin{array}{l}\text { Exon 2- Foward }{ }^{5^{\prime} 3^{\prime}} \text { catcctaatgactctttcctcag } \\
\text { Reverse }{ }^{5^{\prime} 3^{\prime}} \text { cagcagcgatggagagaacatac }\end{array}$ & 163 & 59 \\
\hline & 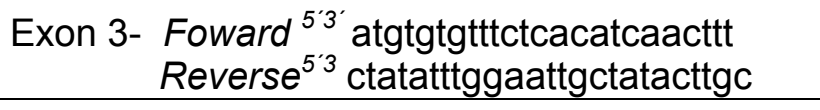 & 217 & 59 \\
\hline & $\begin{array}{r}\text { Exon 4A- Foward }{ }^{5^{\prime} 3^{\prime}} \text { atagtcttctaatttcactgtggt } \\
\text { Reverse } \\
5^{5} 3^{\prime} \text { cttagatataattcctctcaaacc }\end{array}$ & 414 & 55 \\
\hline & $\begin{array}{r}\text { Exon 4B- Foward }{ }^{5^{\prime} 3^{\prime}} \text { cagccttcttctcttaatcacaa } \\
\text { Reverse }{ }^{3^{3}} \text { Tgagctatcagcatttcctaattt }\end{array}$ & 421 & 59 \\
\hline & $\begin{array}{r}\text { Exon } 4 \mathrm{C} \text { - Foward } \text { Foverse }^{5^{3} 3} \text { ccacctactgatggttacatatac } \\
\text { Revatggacacctaattctaatg }\end{array}$ & 403 & 59 \\
\hline
\end{tabular}




\subsubsection{Cromatografia líquida denaturante de alta performance (dHPLC)}

O produto de PCR foi analisado pelo equipamento Wave Nucleic Acid Fragment Analysis System (Transgenomic, EUA) que é um sistema de Cromatografia Líquida Desnaturante de Alta Performance (Denaturing High Performance Liquid Chromatography -dHPLC) utilizado para o rastreamento de mutações e polimorfismos por pareamento iônico a partir de DNA amplificado por PCR. Esta metodologia utiliza uma amostra de DNA sabidamente não mutada (controle) como referência, para a qual são estabelecidas as condições ideais de denaturação e renaturação com base no número de pares de base e na seqüência de nucleotídeos, utilizando a temperatura como fator regulador. Três temperaturas foram utilizadas na análise de cada um dos exons dos três genes, e estas temperaturas foram estabelecidas utilizando-se o software WAVEMaker.

As amostras foram submetidas ao processo de denaturação de acordo com temperatura estabelecida pelo software WAVEMaker e, no momento da renaturação, poderia haver a formação de (Figura 5): (1) heteroduplexes (pareamento entre um alelo normal e um alelo mutado) quando a mutação ou polimorfismo estava presente em heterozigose; (2) homoduplexes selvagens (pareamento entre dois alelos normais) ou (3) homoduplexes mutados (pareamento entre dois alelos mutados). Os possíveis híbridos formados diferem entre si em sua termoestabilidade. Durante a separação dos fragmentos na coluna de cromatografia, após a injeção de $8 \mu \mathrm{L}$ de cada uma das amostras, heteroduplexes e homoduplexes 
originam cromatogramas diferentes: a presença de um pico significa ausência de mutação ou polimorfismo e cromatogramas complexos (dois ou mais picos) indicam a presença de um alelo normal e um alelo mutado ou polimórfico. Para se afastar a presença de mutações em homozigose, as amostras de DNA que geraram um único pico foram misturadas ao produto de PCR de um controle sabidamente não mutado para que ocorresse a formação dos heteroduplexes.

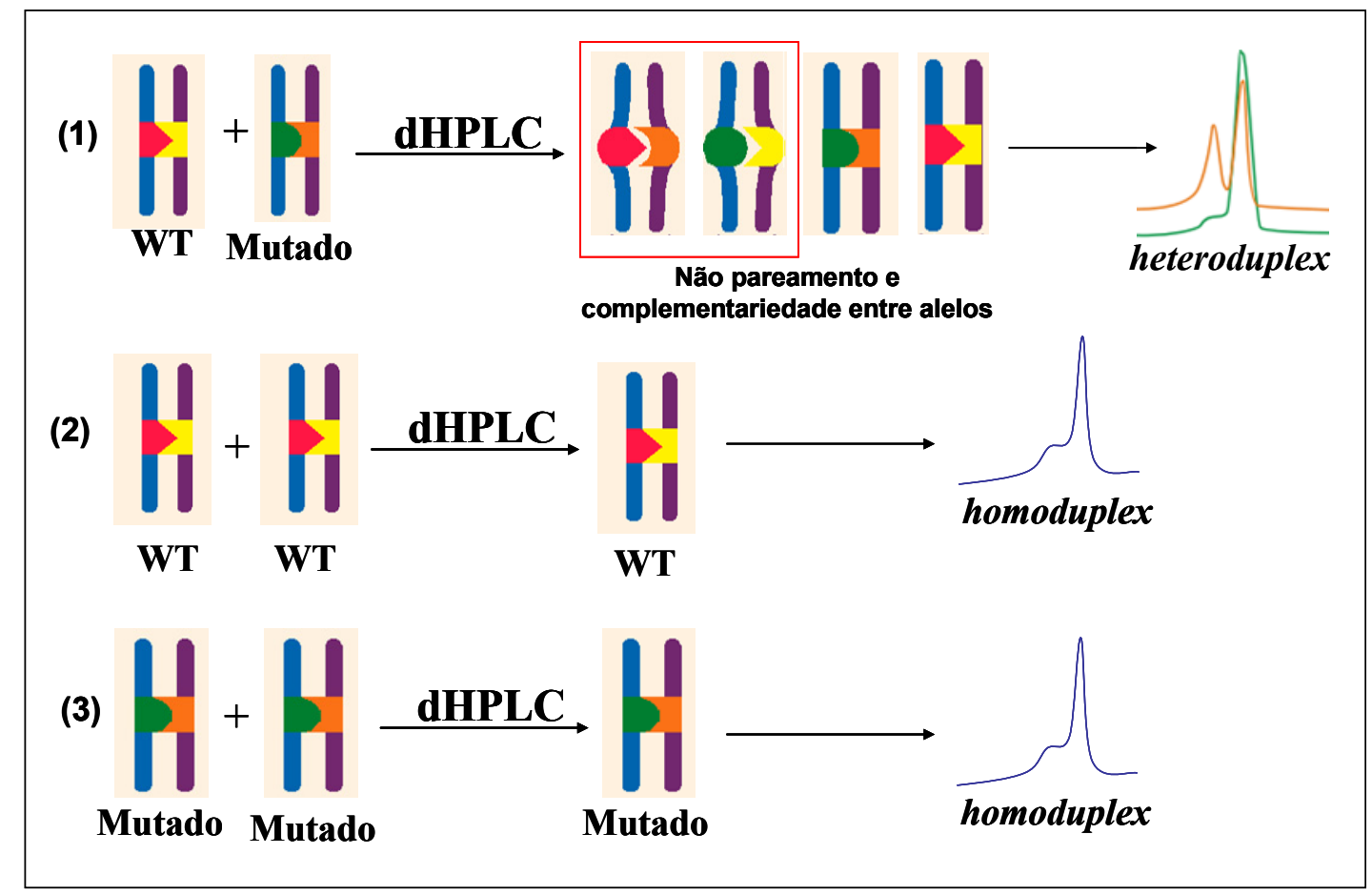

Figura 5: Possíveis formações após pareamento entre alelos na cromatografia liquida denaturante de alta performance (dHPLC) (1) heteroduplexes (pareamento entre um alelo selvagem e um alelo mutado) quando a mutação ou polimorfismo está presente em heterozigose; (2) homoduplexes selvagens (pareamento entre dois alelos selvagens) ou (3) homoduplexes mutados (pareamento entre dois alelos mutados). 
Os exons dos pacientes que apresentaram um cromatograma sugestivo da presença de mutação ou polimorfismo ao dHPLC foram submetidos ao seqüenciamento automático.

\subsubsection{Seqüenciamento automático}

O seqüenciamento foi realizado a partir do produto de PCR previamente purificado. A purificação foi realizada a partir de $5 \mu \mathrm{L}$ do produto de PCR acrescentados de $1 \mathrm{U}$ da enzima exonuclease (Amersham Bioscience) e $1 U$ da enzima fosfatase alcalina de camarão (Amersham Bioscience), que são aquecidos a $80^{\circ} \mathrm{C}$ por $15 \mathrm{~min}$, e a seguir, resfriados até $37^{\circ} \mathrm{C}$ e mantidos a esta temperatura por $15 \mathrm{~min}$.

O seqüenciamento foi realizado em equipamento MegaBace-1000 (GE Healthcare, US), utilizando-se o conjunto de reagentes DYEnamic ET dye terminator (Amersham Bioscience). A reação é preparada conforme resultado da análise quantitativa da banda correspondente a cada uma das amostras, previamente padronizada na quantidade aproximada de $60 \mathrm{ng}$. Foram adicionados a $2 \mu \mathrm{L}$ da amostra purificada: $4 \mu \mathrm{L}$ do reagente de seqüenciamento premix, $1 \mu \mathrm{L}$ do iniciador à 5 pmol e $3 \mu \mathrm{L}$ de $\mathrm{H}_{2} \mathrm{O}$ milliQ autoclavada. A reação foi levada ao termociclador por 30 ciclos de 10 seg de

denaturação a $95{ }^{\circ} \mathrm{C}, 5 \mathrm{seg}$ de anelamento a $50{ }^{\circ} \mathrm{C}, 1 \mathrm{~min}$ de extensão a $60^{\circ} \mathrm{C}$. Após 30 ciclos, foram adicionados às amostras: $20 \mu \mathrm{L}$ de isopropanol a $80 \%$ que após agitação foram centrifugadas por 35 min à 4.000 rpm em temperatura ambiente. Após centrifugação, o sobrenadante foi desprezado 
por inversão, centrifugando-se a placa invertida sob sustentação de um papel absorvente por $1 \mathrm{~min}$ a $600 \mathrm{rpm}$. A seguir, foram adicionados $200 \mu \mathrm{L}$ de etanol a $70 \%$ e a placa foi vedada, agitada por aproximadamente 1 min e centrifugada por $10 \mathrm{~min}$ a $4.000 \mathrm{rpm}$ em temperatura ambiente. Após centrifugação, o sobrenadante foi desprezado por inversão, centrifugandose, a seguir, a placa invertida sob sustentação de papel absorvente por 1 min a $600 \mathrm{rpm}$. Após secagem por aproximadamente $15 \mathrm{~min}$, as amostras foram ressuspendidas em $10 \mu \mathrm{L}$ da solução loading Megabace e injetadas no aparelho, conforme parâmetros de injeção que variaram de acordo com o tamanho do fragmento a ser analisado.

As seqüências de nucleotídeos dos fragmentos obtidas após seqüenciamento foram comparadas à seqüência dos genes depositada no GeneBank, utilizando-se o programa Seqman (Software DNA Star).

\subsubsection{Análise estatística}

Para estabelecer se a freqüência de um alelo polimórfico foi diferente entre a população afetada e a população controle não afetada, foi calculada a razão $z$ (probabilidade bi-caudal) para a significância da diferença entre duas proporções independentes, usando-se o programa disponível no site http://faculty.vassar.edu/lowry/VassarStats, sendo considerado estatístico um valor de $p<0,05$ 
4. RESULTADOS 


\section{Resultados}

\subsection{Estudo do gene VHL}

A análise do amplicon VHL 1A por cromatografia líquida denaturante de alta performance (dHPLC) evidenciou dois padrões de cromatogramas em fragmentos amplificados a partir de DNA obtido de dois controles normais, conforme demonstrado na Figura 6 (Painel $A$ ). O seqüenciamento automático foi, então realizado para todas as amostras, evidenciando a presença de um polimorfismo (c - 195 G>A), já descrito no banco de SNPs (single nucleotide polimorphisms) do NIH (www.ncbi.nlm.nih.gov/SNP). A seqüência selvagem apresenta a base $G$, que pode ser substituída pela base A, 195 nucleotídeos 5' ao códon de início da tradução (ATG), em heterozigose ou em homozigose (Figura 6 - Painel B). O alelo G ocorreu em $41,4 \%$ e o alelo A ocorreu em $58,6 \%$ do total de alelos dos pacientes estudados. Em estudo realizado em população africana, o alelo $G$ foi descrito em $22,6 \%$ e o alelo $\mathrm{A}$ em $71,4 \%$ dos indivíduos, e em estudo realizado em população caucasiana, o alelo $\mathrm{G}$ teve freqüência de $58,7 \%$ e o alelo A de 41,3\% (www.ncbi.nlm.nih.gov/SNP).

Não foram identificados outros polimorfismos ou mutações neste amplicon. 


\section{Painel A}
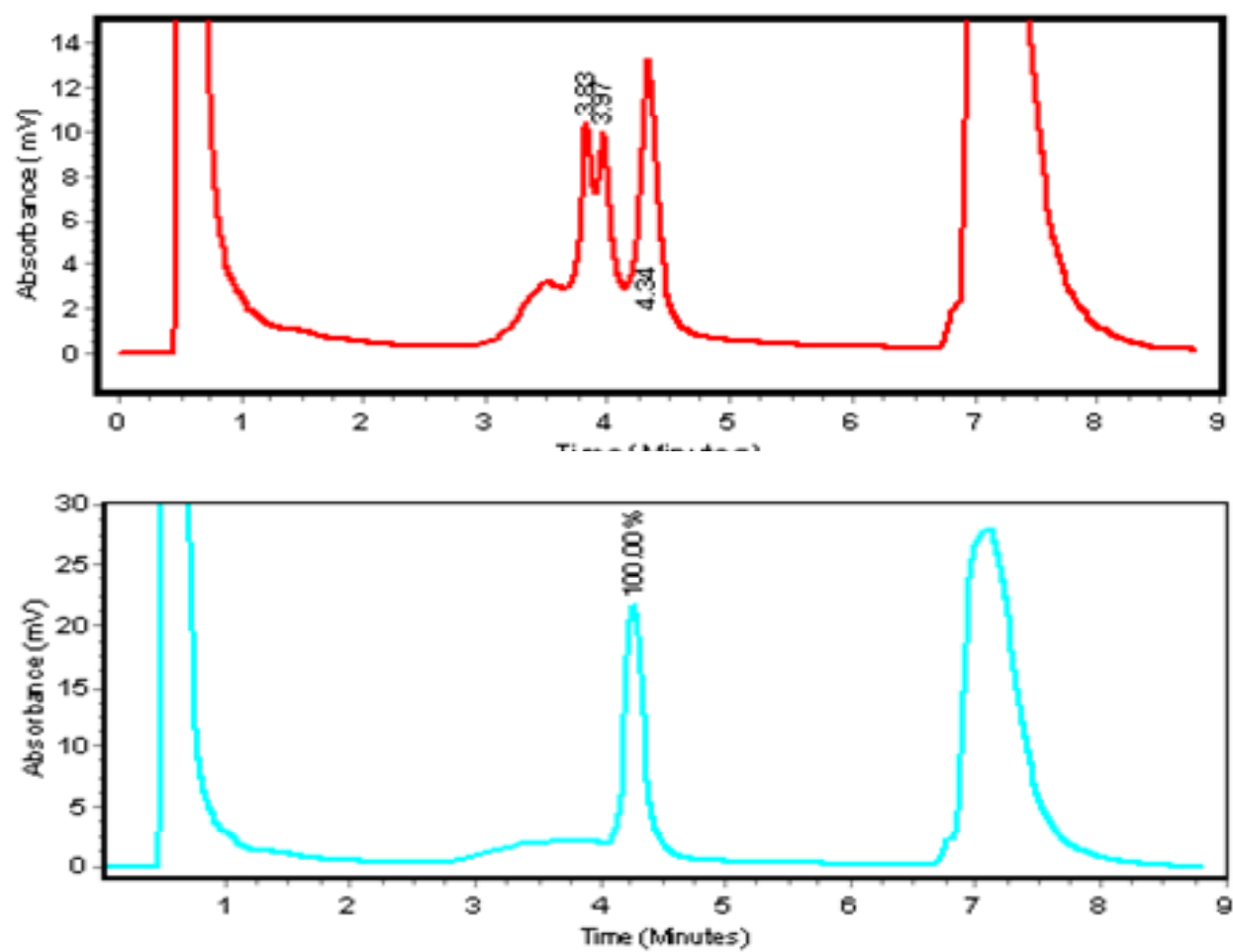

\section{Painel B}
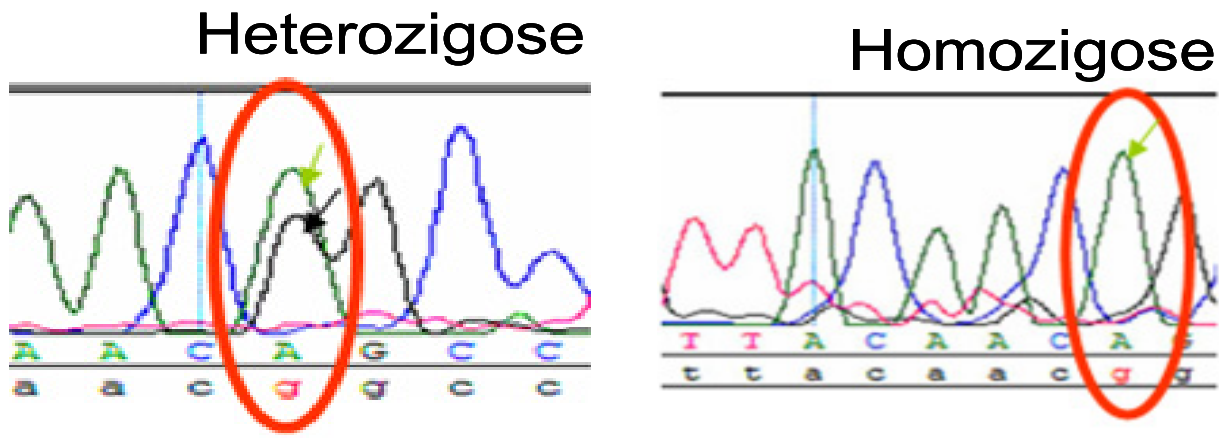

Figura 6 - Painel A: Padrões de cromatograma ao dHPLC do amplicon VHL1A amplificado a partir de DNA obtido de dois controles normais.

Painel B: Eletroferogramas do amplicon VHL1A demonstrando a troca da base $G$ pela base A 195 nucleotídeos 5' ao códon de início da tradução (c $195 \mathrm{G}>\mathrm{A}$ ) em heterozigose e em homozigose. 
A análise do amplicon VHL1B evidenciou cromatogramas alterados em dois pacientes. A Figura 7 (Painel A) demonstra cromatogramas de quatro pacientes comparados com um controle normal, sendo que os pacientes 13,15 e 33 apresentaram cromatogramas iguais ao controle, enquanto o cromatograma do paciente 14 foi diferente. $O$ paciente 31 apresentou cromatograma semelhante ao paciente 14 e ambos tiveram estes amplicons seqüenciados (Figura 7 - Painel B), demonstrando-se um polimorfismo intrônico previamente descrito, a substituição da base $C$ pela base $\mathrm{T}$ em heterozigose no nucleotídeo 77 localizado 5 ' ao primeiro nucleotídeo do exon 1 (c. - 77 C>T). Segundo banco de dados consultado (www.ncbi.nlm.nih.gov/SNP), a frequência do alelo C foi de $96,4 \%$ e a freqüência do alelo $T$ foi de $3,6 \%$ em estudo que incluiu caucasianos, africanos e hispânicos. Os amplicons dos pacientes 34, 35 e 36 foram submetidos ao seqüenciamento automático sem análise prévia pela técnica de dHPLC e não apresentaram alterações.

Os exons 2 e 3 do gene VHL não apresentaram cromatogramas suspeitos após análise por dHPLC. 


\section{Painel A}
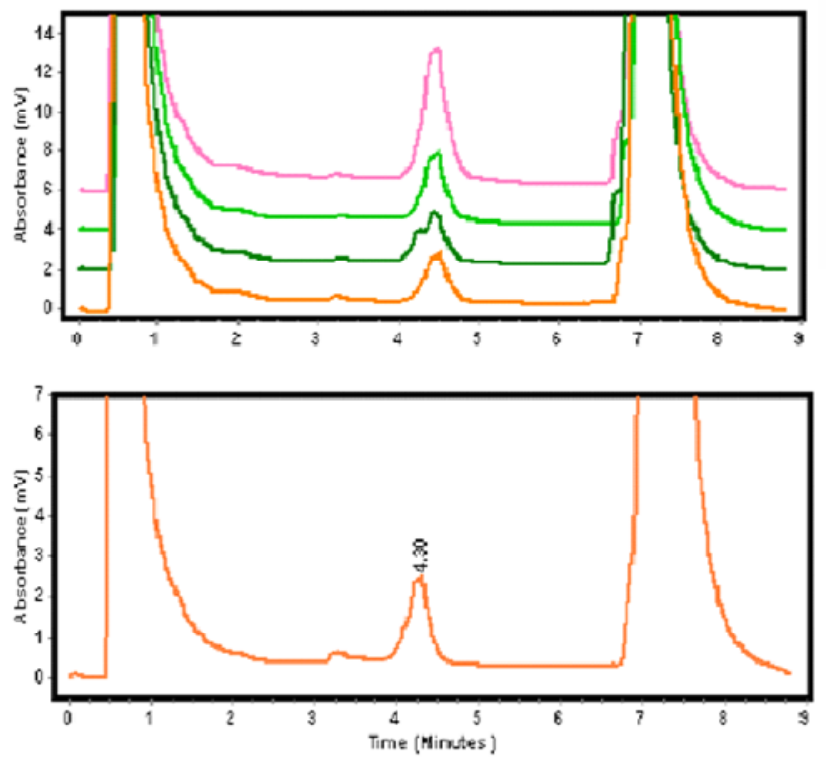

- ondroles

\section{Painel B Heterozigose C>T}

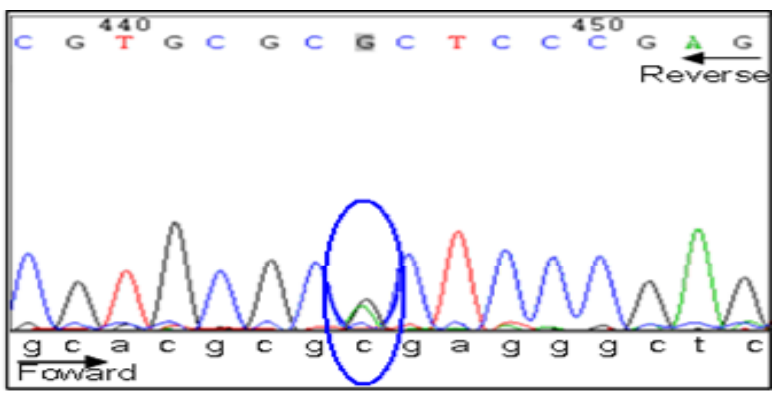

Figura 7 - Painel A: Padrões de cromatograma ao dHPLC do amplicon VHL1B amplificado a partir de DNA obtido de quatro pacientes $(13,14,15 \mathrm{e}$ 33) comparados com o cromatograma de um controle normal. Observa-se que o cromatograma do paciente 14 é diferente dos demais cromatogramas. Painel B: Eletroferograma representativo do amplicon VHL 1B dos pacientes 14 e 31, demonstrando a troca da base $C$ pela base $T$ em heterozigose no nucleotídeo 77 localizado 5' ao primeiro nucleotídeo do exon 1 (c. -77 C>T). 


\subsection{Estudo do gene SDHB}

A análise do gene SDHB ao dHPLC evidenciou seis cromatogramas suspeitos em cinco pacientes. O exon 3 do gene SDHB apresentou cromatogramas complexos nos pacientes 10,11 e 35 , conforme demonstrado na Figura 8, Painel A). O seqüenciamento destes amplicons (Figura 8, Painel B) demonstrou a substituição da base $G$ pela base $T$ no nucleotídeo 36 localizado 5' ao primeiro nucleotídeo do exon 2 (c.201 - 36 G>T) em heterozigose. Trata-se de um polimorfismo intrônico, previamente descrito (http://www.ncbi.nlm.nih.gov/SNP) com freqüência de $97 \%$ para o alelo $G$ e de $3 \%$ para o alelo $T$ em população mista de africanos, americanos, europeus e chineses.

A análise do exon 4 do gene SDHB evidenciou um cromatograma complexo no paciente 6 (Figura 9, Painel A) e o seqüenciamento subseqüente demonstrou a presença de uma mutação previamente descrita no nucleotídeo 293, onde ocorre a substituição da base $\mathrm{G}$ pela base A (c. 293 G>A) (Figura 9, Painel B). Esta troca de bases resulta na substituição de uma cisteína por uma tirosina e sabidamente confere susceptibilidade ao desenvolvimento de feocromocitomas e paragangliomas, conforme reportado no banco de dados que contém as variantes alélicas já descritas nas seqüências dos genes $\mathrm{SDH}$ envolvidas no desenvolvimento de feocromocitomas, paragangliomas e deficiência do complexo II mitocondrial ("The SDH mutation database"; http://chromium.liacs.nl/lovd sdh/index.php). 


\section{Painel A}

SDHB exon 3

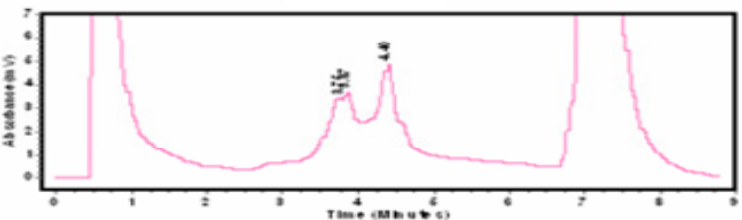

10. SDHB 3

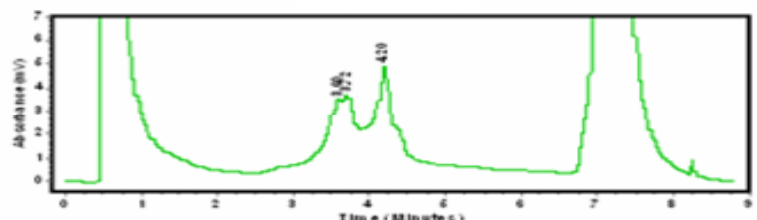

11. SDHB 3

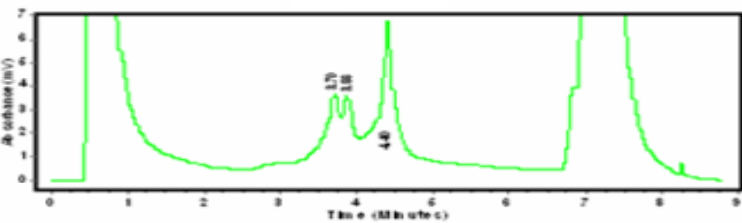

35. SDHB 3

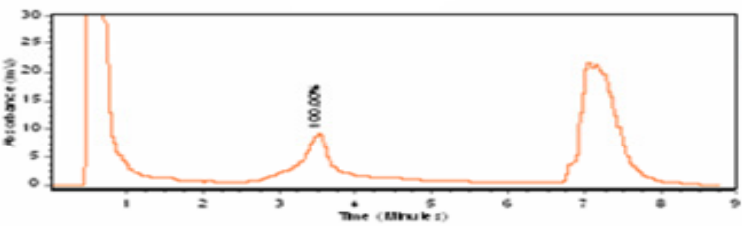

controle normal

Painel B

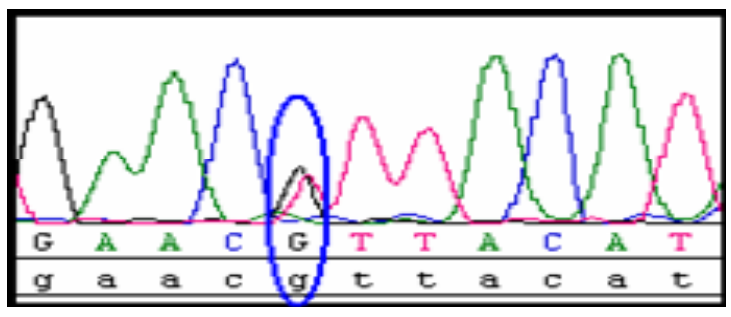

Figura 8 - Painel A: Cromatogramas ao dHPLC do amplicon SDHB 3 dos pacientes 10, 11 e 35 com picos complexos (heteroduplex) comparados ao cromatograma do controle normal.

Painel B: Eletroferograma representativo do amplicon SDHB 3 dos pacientes 10, 11 e 35, demonstrando a troca da base $G$ pela base $T$, em heterozigose, no nucleotídeo 36 localizado 5' ao primeiro nucleotídeo do exon 2 (c.201-36 G>T). 


\section{Painel A}

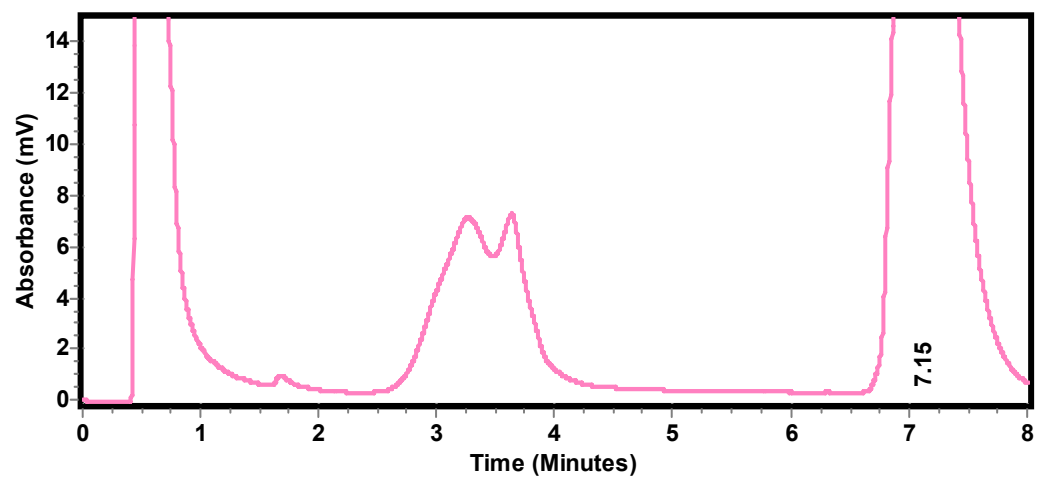

Painel B

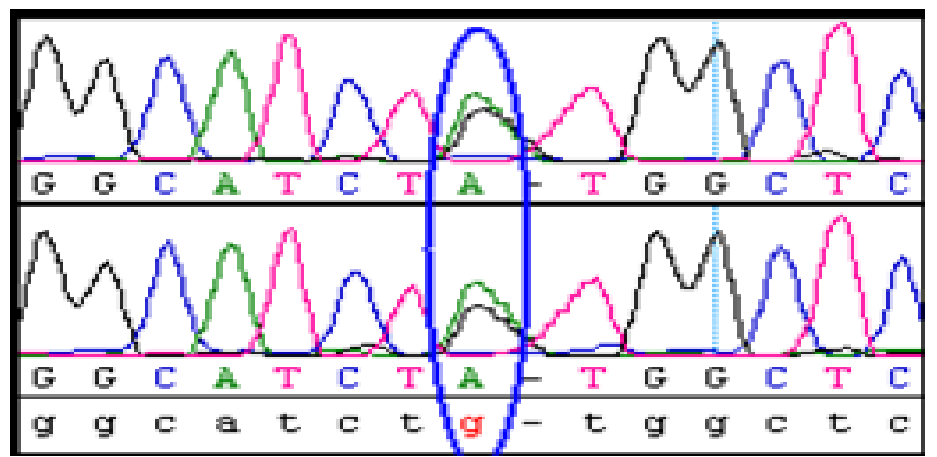

Figura 9 - Painel A: Cromatogramas ao dHPLC do amplicon SDHB 4 do paciente 6 com picos complexos (heteroduplex).

Painel B: Eletroferograma do amplicon SDHD 4 do paciente 6 demonstrando a substituição da base $G$ pela base A no nucleotídeo 293 (c. 293 G>A) em heterozigose.

A análise do amplicon SDHB 5 por dHPLC demonstrou dois cromatogramas suspeitos, nos pacientes números 15 e 35 , conforme demonstrado na Figura 10, Painel A. No seqüenciamento do amplicon do paciente 35 (Figura 10, Painel B), observou-se a substituição da base G pela base $A$, em heterozigose, no nucleotídeo 540 do exon 5 (c.540 G>A). Esta substituição, que não determina troca de aminoácidos na proteína (mutação 
silenciosa), não está descrita em nenhum dos bancos de dados consultados (http://www.ncbi.nlm.nih.gov/entrez, http://www.ensembl.org

e http://chromium.liacs.nl/lovd sdh/index.php). O seqüenciamento do exon 5 do gene SDHB de 100 indivíduos controles normais não evidenciou a substituição c.540 G>A em nenhum dos 200 alelos pesquisados.

O seqüenciamento do amplicon SDHB 5 do paciente 15 evidenciou a presença de um polimorfismo previamente descrito ("The SDH mutation database"; http://chromium.liacs.nl/lovd sdh/index.php), onde ocorre a substituição da base T pela base C no nucleotídeo 487 (c. 487 T>C) em heterozigose (Figura 10, Painel C).

Os demais exons do gene SDHB não apresentaram alterações. Um resumo dos achados referentes ao gene SDHB está demonstrado na Tabela 5. 


\section{Painel A}
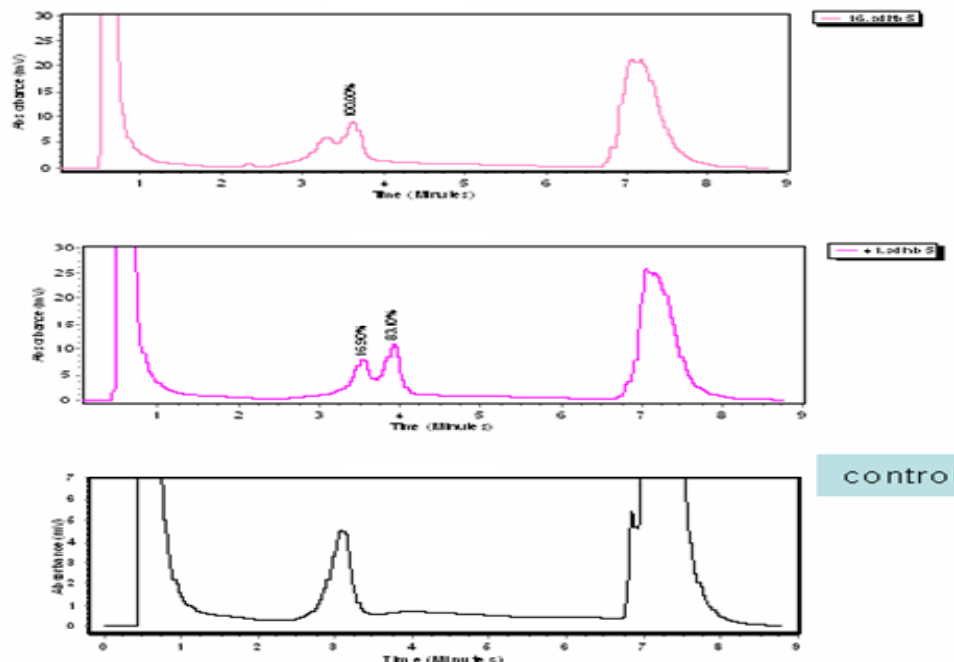

controle normal

Painel B

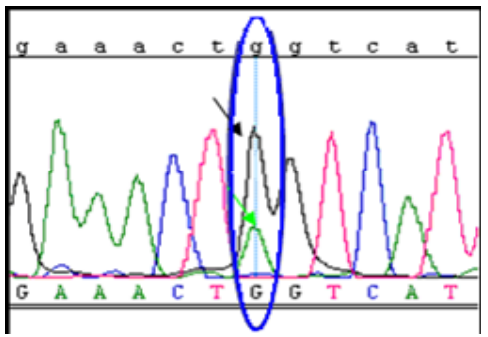

Painel C

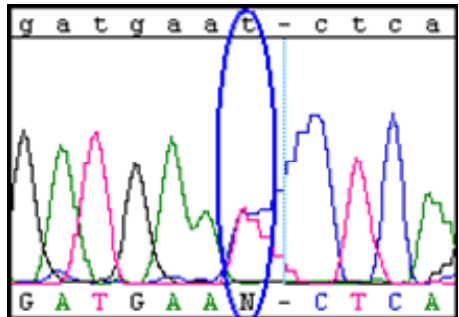

Figura 10 - Painel A: Cromatogramas ao dHPLC do amplicon SDHB 5 dos pacientes 15 e 35 com picos complexos (heteroduplex) comparados ao cromatograma do controle normal.

Painel B: Eletroferograma do amplicon SDHB 5 do paciente 35 demonstrando a troca da base $G$ pela base $A$, em heterozigose, no nucleotídeo 540 do exon 5 (c.540 G>A).

Painel C: Eletroferograma do amplicon SDHB 5 do paciente 15 demonstrando a substituição da base $T$ pela base $C$, em heterozigose, no nucleotídeo 487 (c.487 T>C). 
Tabela 5: Resumo das alterações encontradas no gene SDHB.

\begin{tabular}{|c|c|c|c|c|c|}
\hline Paciente & $\begin{array}{l}\text { I. D. } \\
\text { (anos) }\end{array}$ & $\begin{array}{c}\text { Apresentação } \\
\text { Clínica }\end{array}$ & $\begin{array}{c}\text { Classificação } \\
\text { histológica }\end{array}$ & $\begin{array}{c}\text { Amplicon } \\
\text { alterado ao } \\
\text { dHPLC }\end{array}$ & $\begin{array}{c}\text { Resultado do } \\
\text { seqüenciamento }\end{array}$ \\
\hline & 18 & Paraganglioma & Benigno & SDHB 4 & $\begin{array}{c}\text { c.293 G>A } \\
\text { (Mutação em } \\
\text { heterozigose) }\end{array}$ \\
\hline 10 & 20 & Feocromocitoma & Benigno & SDHB 3 & $\begin{array}{c}\text { c.201-36 G>T } \\
\text { (Polimorfismo em } \\
\text { heterozigose) }\end{array}$ \\
\hline 11 & 38 & Paraganglioma & Benigno & SDHB 3 & $\begin{array}{c}\text { c.201-36 G>T } \\
\text { (Polimorfismo em } \\
\text { heterozigose) }\end{array}$ \\
\hline 15 & 28 & Feocromocitoma & Benigno & SDHB 5 & $\begin{array}{c}\mathrm{c} .487 \mathrm{~T}>\mathrm{C} \\
\text { (Polimorfismo em } \\
\text { heterozigose) }\end{array}$ \\
\hline \multirow[t]{2}{*}{35} & 19 & Paraganglioma & Benigno & SDHB 3 & $\begin{array}{c}\text { c.201-36 G>T } \\
\text { (Polimorfismo em } \\
\text { heterozigose) }\end{array}$ \\
\hline & & & & SDHB 5 & $\begin{array}{c}\text { c.540 G>A } \\
\text { (Mutação silenciosa } \\
\text { em heterozigose) }\end{array}$ \\
\hline
\end{tabular}

I. D.: Idade ao Diagnóstico 


\subsection{Estudo do gene SDHD}

A análise do gene SDHD ao dHPLC, evidenciou 10 cromatogramas suspeitos em oito pacientes. O amplicon SDHD 3 do paciente 24 apresentou um cromatograma suspeito, conforme demonstrado na Figura 11, Painel A. O seqüenciamento deste amplicon (Figura 11, Painel B) evidenciou a substituição da base C pela base T, em heterozigose, no nucleotídeo 204 (c. 204 C>T), substituição esta que não determina troca de aminoácidos. No "The SDH mutation database" (http://chromium.liacs.nl/lovd sdh/index.php), esta substituição é descrita como um polimorfismo presente em 2,8 a 4,4\% dos indivíduos normais. 


\section{Painel A}
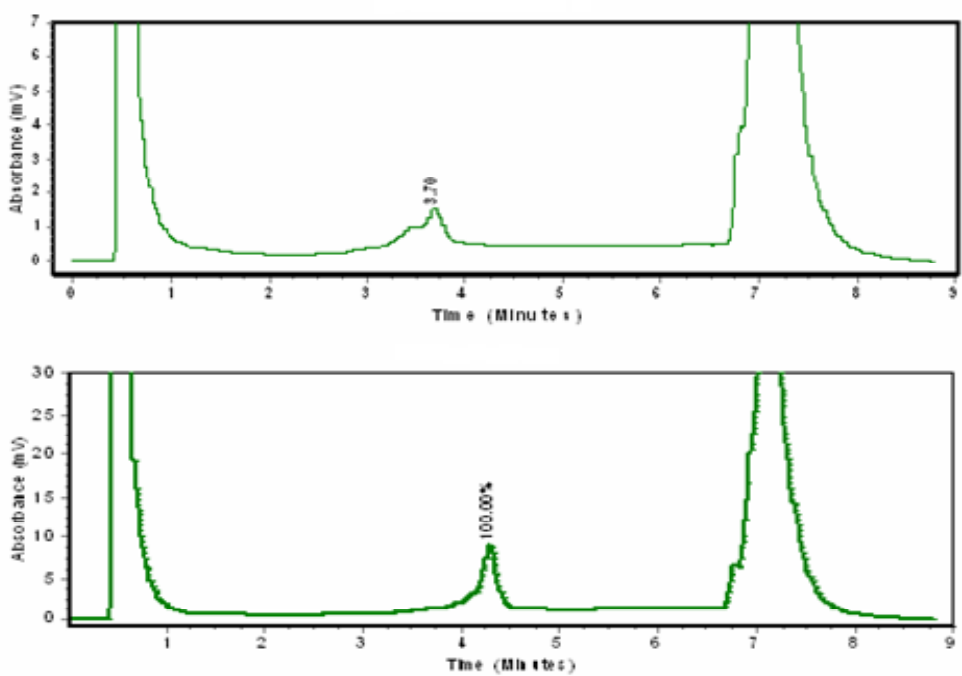

Painel B

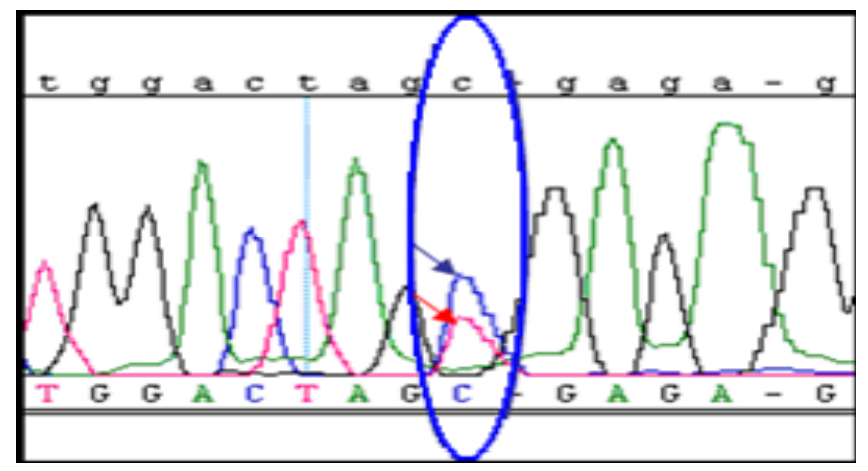

Figura 11 - Painel A: Cromatograma ao dHPLC do amplicon SDHD 3 do paciente 24 comparado ao cromatograma do controle normal.

Painel B: Eletroferograma do amplicon SDHD 3 do paciente 24 demonstrando a troca da base $\mathrm{C}$ pela base $\mathrm{T}$, em heterozigose, no nucleotídeo 204 (c.204 C>T). 
A análise do amplicon 4A do gene SDHD ao dHPLC evidenciou um cromatograma suspeito no paciente 16 (Figura 12, Painel A), portador de paraganglioma e feocromocitoma maligno. Este mesmo paciente também apresentou cromatograma suspeito após análise do amplicon 4C (Figura 12, Painel B), assim como sete outros pacientes, de números 6, 21, 24, 29, 31, 34, e 38. O seqüenciamento do amplicon $4 \mathrm{~A}$ no paciente 16 foi realizado e demonstrou uma variante alélica intrônica já descrita (http://www.ncbi.nlm.nih.gov/SNP), na qual ocorre uma substituição em heterozigose da base $\mathrm{T}$ pela base $\mathrm{C}$ no nucleotídeo 32 localizado 5' ao primeiro nucleotídeo do exon 4 (c.315 - 32 T>C). No "The SDH mutation database" (http://chromium.liacs.nl/lovd sdh/index.php), esta substituição também é descrita como um polimorfismo presente em $4,4 \%$ dos indivíduos normais. (Figura 12, Painel C).

O seqüenciamento do amplicon 4C do paciente 16 evidenciou uma substituição da base A pela base $G$ no nucleotídeo 803 localizado 3' ao códon de término da tradução (TGA) (c.*803 $A>G$ ), que altera a seqüência AATAAA para AATGAA (Figura 12, Painel D). Esta seqüência, localizada na região 3' não codificante do gene, corresponde a região de clivagem do mRNA para inserção da cauda Poli(A). 


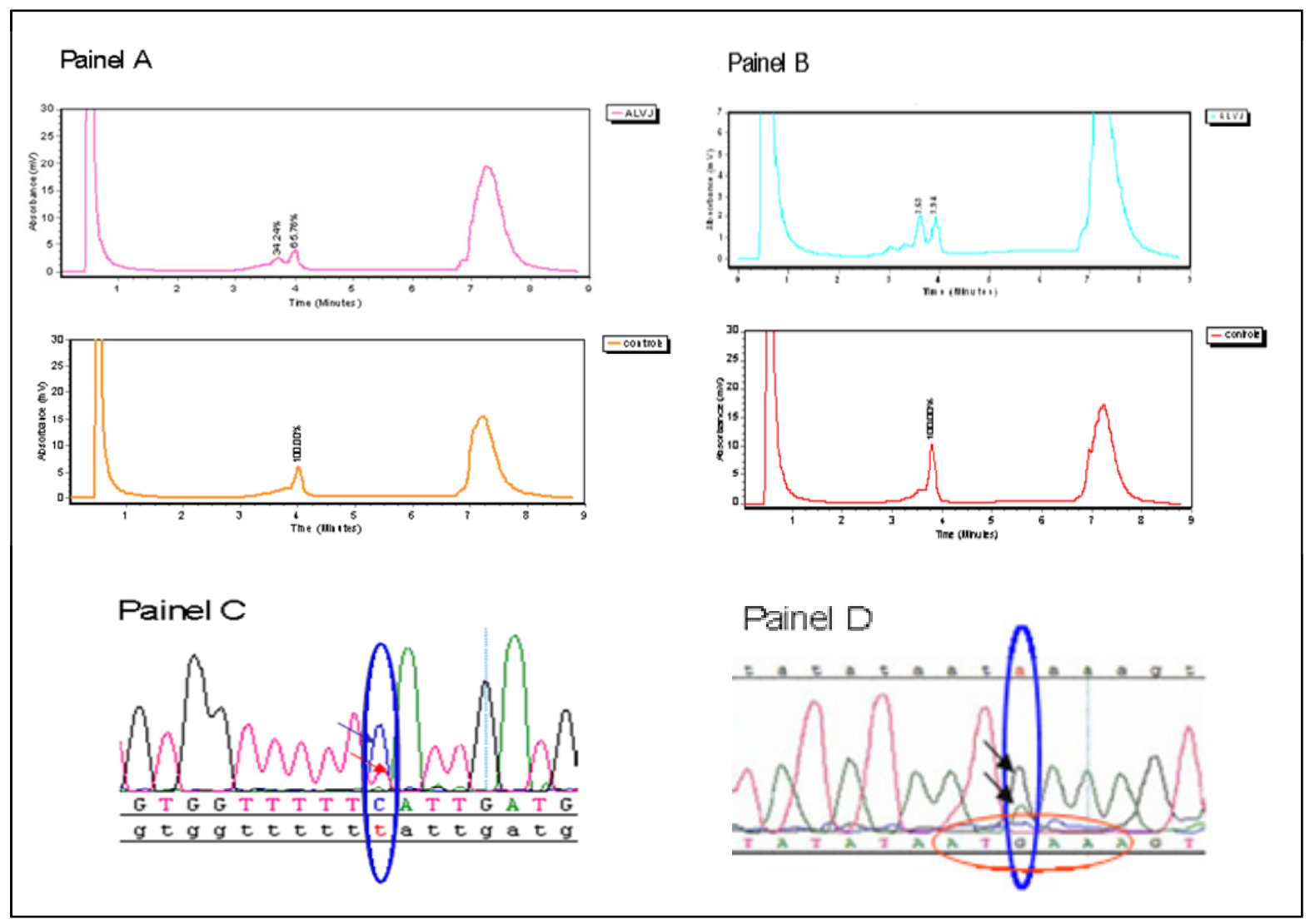

Figura 12 - Painel A: Cromatograma ao dHPLC do amplicon SDHD 4A do paciente 16 comparado ao cromatograma do controle normal.

Painel B: Cromatograma ao dHPLC do amplicon SDHD 4C do paciente 16 comparado ao cromatograma do controle normal.

Painel C: Eletroferograma do amplicon SDHD 4A do paciente 16 demonstrando a substituição em heterozigose da base $T$ pela base $C$ no nucleotídeo 32 localizado 5' ao primeiro nucleotídeo do exon 4 (c.315 - 32 $\mathrm{T}>\mathrm{C})$.

Painel D: Eletroferograma do amplicon SDHD 4C do paciente 16 demonstrando a substituição em heterozigose da base $A$ pela base $G$ no nucleotídeo 803 localizado 3' ao códon de término da tradução (TGA) (c. ${ }^{*} 803 A>G$ ). 
O seqüenciamento do amplicon SDHD 4C dos outros sete pacientes $(6,21,24,29,31,34$, e 38) que apresentaram cromatogramas suspeitos de mutações ao dHPLC demonstrou que seis desses pacientes $(6,21,24,29$, 34, e 38) apresentaram a mesma substituição identificada no paciente 16 (c. ${ }^{*} 803 \mathrm{~A}>\mathrm{G}$ ), quatro em heterozigose e dois em homozigose (Tabela 6). $\mathrm{O}$ seqüenciamento do amplicon 4C de 100 indivíduos controles normais evidenciou a substituição c. ${ }^{\star} 803 \mathrm{~A}>\mathrm{G}$ em três indivíduos não portadores de feocromocitoma ou paraganglioma, em dois indivíduos em homozigose e em um indivíduo em heterozigose. Portanto, a variante c. ${ }^{*} 803$ A $>G$ foi encontrada em nove de 76 alelos dos 38 pacientes $(11,8 \%)$ e em cinco de 200 alelos de 100 controles não afetados (2,5\%), sendo significativamente mais freqüente na população afetada $(p=0,0016)$.

O paciente 31 apresentou ao seqüenciamento (Figura 13) a substituição da base C pela base T em heterozigose, no nucleotídeo 612 localizado 3' ao códon do término da tradução (TGA) (c. ${ }^{*} 612$ C>T). Esta variante alélica está descrita em dois bancos de dados (http://www.dsi.univparis5.fr/genatlas/; $\quad$ http://www.ncbi.nlm.nih.gov/entrez), porém, sua freqüência não é mencionada.

Outra alteração no amplicon SDHD 4C foi demonstrada no paciente 6, a substituição da base T pela base C, em heterozigose, no nucleotídeo 799 localizado 3' ao códon de término da tradução (TGA) (c. 799 T>C), conforme demonstrado na Figura 14. A descrição desta substituição, em uma região não codificante, não foi encontrada em nenhum dos bancos de dados consultados. 
O seqüenciamento do amplicon 4C de 100 indivíduos controles normais não evidenciou as substituições c.* 612 C>T e c.*799 T>C em nenhum dos 200 alelos pesquisados.

Um resumo dos achados referentes ao gene SDHD está demonstrado na Tabela 6. 
Tabela 6: Pacientes com a substituição c. ${ }^{*} 803$ A>G localizada no amplicon $4 \mathrm{C}$ do gene SDHD.

\begin{tabular}{|c|c|c|c|c|}
\hline Paciente & $\begin{array}{c}\text { Idade ao } \\
\text { dignóstico } \\
\text { (anos) }\end{array}$ & $\begin{array}{c}\text { Apresentação } \\
\text { Clínica }\end{array}$ & $\begin{array}{c}\text { Classificação } \\
\text { histológica }\end{array}$ & $\begin{array}{c}\text { Resultado do } \\
\text { seqüenciamento }\end{array}$ \\
\hline 6 & 18 & Paraganglioma & Benigno & $\begin{array}{c}\text { c. }{ }^{*} 803 \mathrm{~A}>\mathrm{G} \text { em } \\
\text { heterozigose }\end{array}$ \\
\hline 16 & 25 & $\begin{array}{c}\text { Feocromocitoma/ } \\
\text { Paraganglioma }\end{array}$ & Maligno & $\begin{array}{c}\text { c. }{ }^{*} 803 \mathrm{~A}>\mathrm{G} \text { em } \\
\text { heterozigose }\end{array}$ \\
\hline 21 & 40 & Feocromocitoma & Maligno & $\begin{array}{c}\text { c. }{ }^{*} 803 \mathrm{~A}>\mathrm{G} \text { em } \\
\text { heterozigose }\end{array}$ \\
\hline 24 & 15 & Feocromocitoma & Benigno & $\begin{array}{c}\text { c. }{ }^{*} 803 \mathrm{~A}>\mathrm{G} \text { em } \\
\text { heterozigose }\end{array}$ \\
\hline 29 & 21 & Feocromocitoma & Maligno & $\begin{array}{c}\text { c. }{ }^{*} 803 \mathrm{~A}>\mathrm{G} \text { em } \\
\text { homozigose }\end{array}$ \\
\hline 34 & 31 & Paraganglioma & Benigno & $\begin{array}{c}\text { c. }{ }^{*} 803 \mathrm{~A}>\mathrm{G} \text { em } \\
\text { homozigose) }\end{array}$ \\
\hline 38 & 7 & Feocromocitoma & Benigno & $\begin{array}{c}\text { c. }{ }^{*} 803 \mathrm{~A}>\mathrm{G} \text { em } \\
\text { heterozigose }\end{array}$ \\
\hline
\end{tabular}




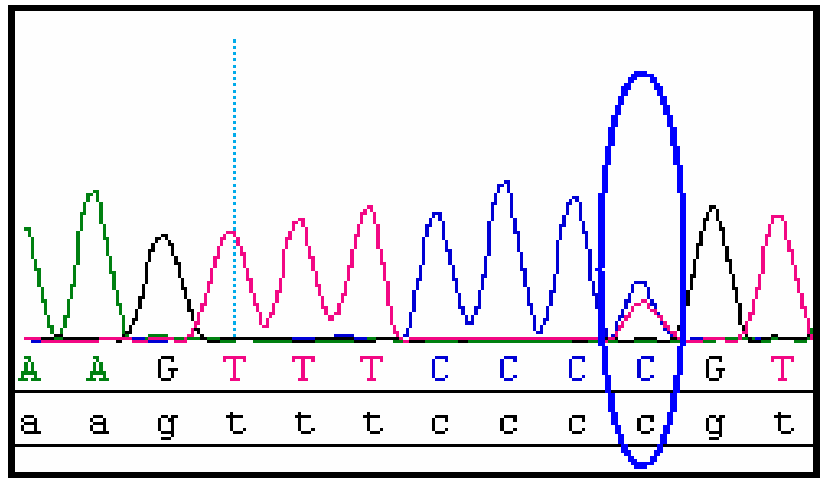

Figura 13: Eletroferograma do amplicon SDHD 4C do paciente 31 demonstrando a substituição da base $C$ pela base $T$ em heterozigose no nucleotídeo 612 localizado 3' ao códon do término da tradução (TGA) (c. $612 \mathrm{C}>\mathrm{T})$.

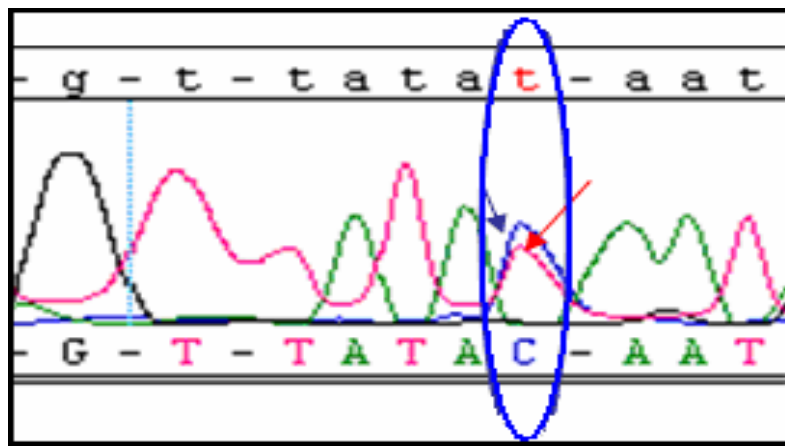

Figura 14: Eletroferograma do amplicon SDHD 4C do paciente 6 demonstrando a substituição da base $T$ pela base $C$, em heterozigose, no nucleotídeo 799 localizado 3' ao códon de término da tradução (TGA) (c. ${ }^{*} 799 \mathrm{~T}>\mathrm{C}$ ). 
Tabela 7: Resumo das alterações encontradas no gene SDHD.

\begin{tabular}{|c|c|c|c|c|c|}
\hline Paciente & $\begin{array}{l}\text { I. D. } \\
\text { (anos) }\end{array}$ & $\begin{array}{l}\text { Apresentação } \\
\text { Clínica }\end{array}$ & $\begin{array}{l}\text { Classificação } \\
\text { histológica }\end{array}$ & $\begin{array}{c}\text { Amplicon } \\
\text { alterado ao } \\
\text { dHPLC }\end{array}$ & Resultado do seqüenciamento \\
\hline 6 & 18 & Paraganglioma & Benigno & SDHD 4C & $\begin{array}{l}\text { c. }{ }^{*} 799 \text { T>C (Mutação em heterozigose) } \\
\text { c. }{ }^{803} \text { A > G (Polimorfismo em heterozigose) }\end{array}$ \\
\hline 16 & 25 & $\begin{array}{l}\text { Feocromocitoma/ } \\
\text { Paraganglioma }\end{array}$ & Maligno & $\begin{array}{l}\text { SDHD 4A } \\
\text { SDHD 4C }\end{array}$ & $\begin{array}{l}\text { c.315-32 T>C (Polimorfismo em heterozigose) } \\
\text { c. }{ }^{*} 803 \text { A>G (Polimorfismo em heterozigose) }\end{array}$ \\
\hline 21 & 40 & Feocromocitoma & Maligno & SDHD 4C & c. ${ }^{\star} 803$ A>G (Polimorfismo em heterozigose) \\
\hline 24 & 15 & Feocromocitoma & Benigno & $\begin{array}{l}\text { SDHD } 3 \\
\text { SDHD 4C }\end{array}$ & $\begin{array}{l}\text { c.204 C>T (Polimorfismo em heterozigose) } \\
\text { c. }{ }^{*} 803 \text { A>G(Polimorfismo em heterozigose) }\end{array}$ \\
\hline 29 & 21 & Feocromocitoma & Maligno & SDHD 4C & c. ${ }^{*} 803$ A>G (Polimorfismo em homorozigose) \\
\hline 31 & 14 & Feocromocitoma & Benigno & SDHD 4C & c. ${ }^{*} 612$ C>T (Mutação em heterozigose) \\
\hline 34 & 31 & Paraganglioma & Benigno & SDHD 4C & c. *803 A>G (Polimorfismo em homozigose) \\
\hline 38 & 7 & Feocromocitoma & Benigno & SDHD 4C & c. ${ }^{*} 803 \mathrm{~A}>\mathrm{G}$ (Polimorfismo em heterozigose) \\
\hline
\end{tabular}

* : Localização na região 3' não codificante.

I.D.: Idade ao diagnóstico. 


\subsection{Resumo dos resultados}

As alterações encontradas nos 38 pacientes estão listadas na Tabela 8. Nenhuma mutação foi encontrada no gene $\mathrm{VHL}$, apenas dois polimorfismos previamente descritos no exon 1, c. $-77 \mathrm{C}>\mathrm{T}$ em dois pacientes e c - $195 \mathrm{G}>\mathrm{A}$ em $58,6 \%$ do total de alelos dos pacientes estudados. No gene SDHB foram encontrados dois polimorfismos previamente descritos (c. 201-36 G>T e c.487 T>C) em quatro pacientes, uma mutação silenciosa não descrita previamente (c.540 G>A) e uma mutação previamente descrita em portadores de feocromocitoma (c. 293 G>A). Um mesmo paciente apresentou a mutação silenciosa c.540 G>A e o polimorfismo c.201-36 G>T. No gene SDHD foram encontrados dois polimorfismos anteriormente descritos (c.204 C>T e c.315-32 T>C) em um paciente cada, uma variante alélica descrita na literatura na região 3' não codificante cuja freqüência nunca foi estudada em outras populações (c. ${ }^{*} 612$ C>T) e duas substituições nunca descritas na literatura na região 3' não codificante (c. ${ }^{*} 799 \mathrm{~T}>\mathrm{C}$ e c. ${ }^{*} 803 \mathrm{~A}>\mathrm{G}$ ). As variantes c. ${ }^{*} 612 \mathrm{C}>\mathrm{T}$ e c. ${ }^{* 799}$ T>C foram detectadas em apenas um paciente cada e não foram encontradas em 200 alelos de controles normais aqui estudados. A variante c. ${ }^{8} 803$ A $>$ G foi encontrada em nove de 76 alelos dos 38 pacientes $(11,8 \%)$ e em cinco de 200 alelos de 100 controles não afetados (2,5\%), sendo, portanto, um polimorfismo significativamente mais freqüente ( $p=0,0016)$ entre os portadores de feocromocitoma ou paraganglioma que entre indivíduos não portadores desses tumores. Dentre os sete pacientes 
portadores do polimorfismo c. ${ }^{*} 803 \mathrm{~A}>\mathrm{G}$, três pacientes heterozigotos para este polimorfismo apresentaram um segundo polimorfismo no gene SDHD, sendo que um desses pacientes (número 6) também apresentava uma mutação no gene SDHB. Dentre os demais quatro pacientes, dois apresentavam o polimorfismo c. ${ }^{\star} 803 \mathrm{~A}>\mathrm{G}$ em homozigose. 
Tabela 8: Resumo das alterações encontradas nos 38 pacientes estudados. * : Localização na região 3' não codificante.

\begin{tabular}{|c|c|c|c|c|c|}
\hline Paciente & $\begin{array}{c}\text { Idade ao dignóstico } \\
\text { (anos) }\end{array}$ & $\begin{array}{c}\text { Apresentação } \\
\text { Clínica }\end{array}$ & $\begin{array}{l}\text { Classificação } \\
\text { histológica }\end{array}$ & $\begin{array}{c}\text { Amplicon alterado ao } \\
\text { dHPLC }\end{array}$ & Resultado do seqüenciamento \\
\hline \multirow[t]{3}{*}{6} & 18 & Paraganglioma & Benigno & SDHB 4 & c.293 G>A (Mutação previamente descrita) \\
\hline & & & & SDHD 4C & c. ${ }^{*} 799$ T>C (Mutação nunca descrita *) \\
\hline & & & & SDHD 4C & c. ${ }^{*} 803$ A>G (Polimorfismo nunca descrito *) \\
\hline 10 & 20 & Feocromocitoma & Benigno & SDHB 3 & c.201-36 G>T (Polimorfismo previamente descrito) \\
\hline 11 & 38 & Paraganglioma & Benigno & SDHB 3 & c.201-36 G>T (Polimorfismo previamente descrito) \\
\hline 14 & 29 & Paraganglioma & Benigno & VHL 1B & c.-77 C>T (Polimorfismo previamente descrito) \\
\hline 15 & 28 & Feocromocitoma & Benigno & SDHB 5 & c.487 T>C (Polimorfismo previamente descrito) \\
\hline \multirow[t]{2}{*}{16} & 25 & Feocromocitoma/ & Maligno & SDHD 4A & c.315-32 T>C (Polimorfismo previamente descrito) \\
\hline & & Paraganglioma & & SDHD 4C & c. ${ }^{*} 803$ A>G (Polimorfismo nunca descrito *) \\
\hline 21 & 40 & Feocromocitoma & Maligno & SDHD 4C & c. ${ }^{*} 803 \mathrm{~A}>\mathrm{G}$ (Polimorfismo nunca descrito *) \\
\hline \multirow[t]{2}{*}{24} & 15 & Feocromocitoma & Benigno & SDHD 3 & c.204 C>T (Polimorfismo previamente descrito) \\
\hline & & & & SDHD 4C & c. ${ }^{*} 803$ A>G (Polimorfismo nunca descrito *) \\
\hline 29 & 21 & Feocromocitoma & Maligno & SDHD 4C & c. ${ }^{*} 803$ A>G (Polimorfismo nunca descrito *) \\
\hline \multirow[t]{2}{*}{31} & 14 & Feocromocitoma & Benigno & VHL 1B & c.-77 C>T (Polimorfismo previamente descrito) \\
\hline & & & & SDHD 4C & c. ${ }^{*} 612$ C>T (Polimorfismo ou mutação? ${ }^{*}$ ) \\
\hline 34 & 31 & Paraganglioma & Benigno & SDHD 4C & c. ${ }^{*} 803$ A>G (Polimorfismo nunca descrito *) \\
\hline \multirow[t]{2}{*}{35} & 19 & Paraganglioma & Benigno & SDHB 3 & c.201-36 G>T (Polimorfismo previamente descrito) \\
\hline & & & & SDHB 5 & c.540 G>A (Mutação silenciosa nunca descrita) \\
\hline 38 & 7 & Feocromocitoma & Benigno & SDHD 4C & c. ${ }^{*} 803$ A >G (Polimorfismo nunca descrito *) \\
\hline
\end{tabular}


5. DISCUSSÃO 


\section{Discussão}

Até poucos anos atrás, considerava-se que aproximadamente $10 \%$ dos feocromocitomas eram hereditários. Um estudo realizado em 2002 por Neumann et al., envolvendo 271 pacientes portadores de feocromocitoma esporádico e outros estudos publicados posteriormente têm mudado este conceito. No estudo de Neumann, $24 \%$ dos pacientes portadores de feocromocitoma ou paraganglioma esporádico eram portadores de mutações nos genes VHL ( $11 \%$ dos casos), SDHB ( $4 \%$ dos casos), SDHD ( $4 \%$ dos casos) e RET ( $5 \%$ dos casos) ${ }^{29}$.

Um estudo de 2005 de Amar et al. também rastreou 258 pacientes portadores de feocromocitoma ou paraganglioma esporádico e detectou mutações em $11,6 \%$ dos casos, sendo $3,5 \%$ no gene $\mathrm{VHL}, 7 \%$ no gene SDHB, $0,8 \%$ no gene SDHD e $0,4 \%$ no gene RET ${ }^{30}$. Verifica-se, desta forma, que o estudo da freqüência de mutações nos genes que conferem susceptibilidade ao feocromocitoma e paraganglioma em grandes casuísticas de portadores de tumores esporádicos varia conforme a população estudada.

No presente estudo, utilizamos a metodologia de dHPLC para rastrear mutações nos genes VHL, SDHB e SDHD em pacientes portadores de feocromocitoma ou, também, paraganglioma esporádicos. A técnica de dHPLC é de fácil execução e de grande acurácia. Klein et cols. verificaram a sensibilidade do mesmo equipamento utilizado nesse estudo (Wave Nucleic Acid Fragment Analysis System) na detecção de mutações do gene VHL em pacientes cujo DNA já havia sido previamente seqüenciado. Dentre as 14 
mutações sabidamente presentes no exon 1 do gene, 13 foram identificadas (93\%). Da mesma forma, 10 de 11 mutações no exon 2 (91\%) e 12 de 13 mutações no exon 3 (92\%) foram identificadas ${ }^{31}$. Nossos achados não permitem conclusões quanto à sensibilidade do equipamento, já que não foram realizados seqüenciamentos sistemáticos de todos os exons em todos os pacientes, mas demonstraram a alta especificidade do método de dHPLC, já que todos os amplicons que apresentaram cromatogramas suspeitos de mutação foram submetidos ao seqüenciamento automático e apresentaram polimorfismos ou mutações, não tendo havido nenhum caso de falso positivo.

Conforme demonstrado pela análise do amplicon 1A do gene VHL, a técnica de dHPLC deve ser utilizada com cautela na avaliação de seqüências de DNA que apresentam muitos polimorfismos, sendo recomendável que se obtenham cromatogramas de diversos controles não afetados e que se proceda ao seqüenciamento posterior para se fazer a correlação entre os cromatogramas obtidos e as seqüências polimórficas a que se referem. Desta forma, quando da avaliação dos cromatogramas dos pacientes, pode-se seqüenciar apenas aqueles cromatogramas que apresentem padrões diferentes daqueles obtidos nos controles não afetados.

No amplicon VHL 1A, onde há apenas um SNP descrito nos bancos de dados disponíveis, observou-se a presença de dois padrões de cromatograma tanto nos amplicons de indivíduos controles quanto nos portadores de feocromocitoma e paraganglioma. Como esta foi a primeira região a ser estudada, quando o grupo ainda estava adquirindo experiência 
com a técnica de dHPLC, optou-se pelo seqüenciamento direto de todas as amostras. Atualmente, com a experiência adquirida com o equipamento, consideramos que somente a análise ao dHPLC em comparação com vários controles não afetados teria sido suficiente para demonstrar a presença do polimorfismo c. - 195 G>A e a ausência de outras mutações neste amplicon. A freqüência do alelo $G$ entre os pacientes estudados foi de $41,4 \%$ e a freqüência do alelo A foi de 58,6\%. O banco de dados do NIH descreve as freqüências dos alelos G e A como sendo, respectivamente, 58,7\% e 41,3\% em população caucasiana.

A análise do fragmento $\mathrm{VHL} 1 \mathrm{~B}$ por dHPLC demonstrou dois pacientes com cromatogramas suspeitos e idênticos entre si, nos quais o mesmo polimorfismo previamente descrito foi observado ao seqüenciamento (c. $-77 \quad \mathrm{C}>\mathrm{T}$ ). Segundo banco de dados consultado (www.ncbi.nlm.nih.gov/SNP), a frequência do alelo C na população estudada (causaciana, africana e hispânica) foi de $96,4 \%$ e a do alelo T foi de 3,6\%. Diferentemente de outros estudos ${ }^{172930}$, não foram encontradas mutações nas regiões codificantes do gene VHL nessa série de portadores de feocromocitoma e paraganglioma esporádicos.

A análise do gene SDHB evidenciou a presença de cromatogramas suspeitos ao dHPLC em seis pacientes, um dos quais (número 35) apresentou alterações em dois amplicons (SDHB 3 e 5). A substituição encontrada no exon 3 do gene SDHB (c.201-36 G>T) no paciente 35, também ocorreu nos pacientes 10 e 11, com idades ao diagnóstico de 19, 20 e 38 anos, respectivamente. Este polimorfismo intrônico, descrito com 
freqüência de $97 \%$ para o alelo $\mathrm{G}$ e de $3 \%$ para o alelo $\mathrm{T}$ em população mista de africanos, africanos americanos, europeus e chineses (http://www.ncbi.nlm.nih.gov/SNP) não está associado ao desenvolvimento de feocromocitoma, conforme descrito no "The SDH mutation database". $\mathrm{Na}$ paciente 35 também foi detectada uma mutação silenciosa em heterozigose (c.540 G>A) no amplicon SDHB 5. Embora esta substituição não resulte em troca de aminoácidos, sua freqüência foi estudada em 100 controles não afetados para determinar se poderia tratar-se de um polimorfismo presente em nossa população, mas a mesma não foi encontrada em nenhum dos 200 alelos estudados de controles não afetados.

A paciente número 6 , portadora de paraganglioma benigno diagnosticado aos 18 anos, apresentou a mutação c.293 G>A no exon 4 do gene SDHB. Esta mutação, que promove a substitução de uma cisteína por uma tirosina, é descrita como deletéria e associada ao desenvolvimento de fecromocitoma de de paraganglioma (http://chromium.liacs.nl/lovd_sdh/index.php). Portanto, nessa série de pacientes, apenas uma mutação deletéria foi detectada na região codificante do gene SDHB (2,6\% dos casos).

A análise do gene SDHD evidenciou a presença de dez cromatogramas suspeitos ao dHPLC em nove pacientes, sendo que três pacientes (números 6, 16 e 24), com idades ao diagnóstico de 18, 25 e 15 anos, apresentaram substituições confirmadas pelo seqüenciamento em duas posições desse gene. O polimorfismo c. 204 C>T, encontrado no exon 3 do paciente 24 , tem uma freqüência na população normal que varia de 2,8 
a 4,4\% e, segundo o "The SDH mutation database", não está associado ao desenvolvimento de feocromocitomas e paragangliomas.

A substituição detectada no amplicon SDHD 4A do paciente 16 (portador de paraganglioma e feocromocitoma maligno) é uma variante alélica intrônica (c. $315 \quad-\quad 32 \quad$ T>C) anteriormente descrita (http://www.ncbi.nlm.nih.gov/SNP) que está presente em $4,4 \%$ da população normal e que não está associado ao desenvolvimento de feocromocitomas, conforme descrito no "The SDH mutation database".

A paciente 6 , portadora da única mutação deletéria encontrada no gene SDHB, apresentou também duas substituições no amplicon 4C nunca antes descritas, ambas na região 3' não codificante: c. ${ }^{\star} 799$ T>C e c. ${ }^{*} 803$ $A>G$. Esta última também detectada nos dois pacientes previamente descritos (16 e 24) e em outros quatro pacientes (21, 29, 34 e 38). Uma terceira substituição foi encontrada na região 3' não codificante (c. *612 C>T) do gene SDHD no paciente 31. Esta variante alélica já foi reportada em dois bancos de dados, (http://www.dsi.univ-paris5.fr/genatlas/; http://www.ncbi.nlm.nih.gov/entrez), mas sua freqüência não está descrita. Tanto a substituição c. ${ }^{*} 799$ T>C como a c. ${ }^{*} 612$ C>T não foram encontradas nos 200 alelos estudados de indivíduos controles não afetados.

Em suma, diferentemente de outros estudos $9,17,18,29,30$, não foram encontradas mutações nas regiões codificantes do gene SDHD nessa série de portadores de feocromocitoma e paraganglioma esporádicos, mas o achado da freqüência do alelo polimórfico c. *803 A>G ser significativamente maior nos portadores de feocromocitoma ou paraganglioma $(11,8 \%)$ em 
relação à população controle não afetada (2,5\%) nos pareceu relevante, especialmente por sua localização e pelo fato de três pacientes apresentarem outras alterações concomitantes no mesmo gene. Na Figura 15 estão representadas as localizações das variantes alélicas encontradas no gene SDHD, da região correspondente ao sinal para poliadenilação AATAAA (Upstream core poliadelination signal - UCPAS), da região correspondente ao Sítio de Clivagem do mRNA, bem como os iniciadores construídos para a amplificação do exon 4 e da região 3' não codificante do gene SDHD. 


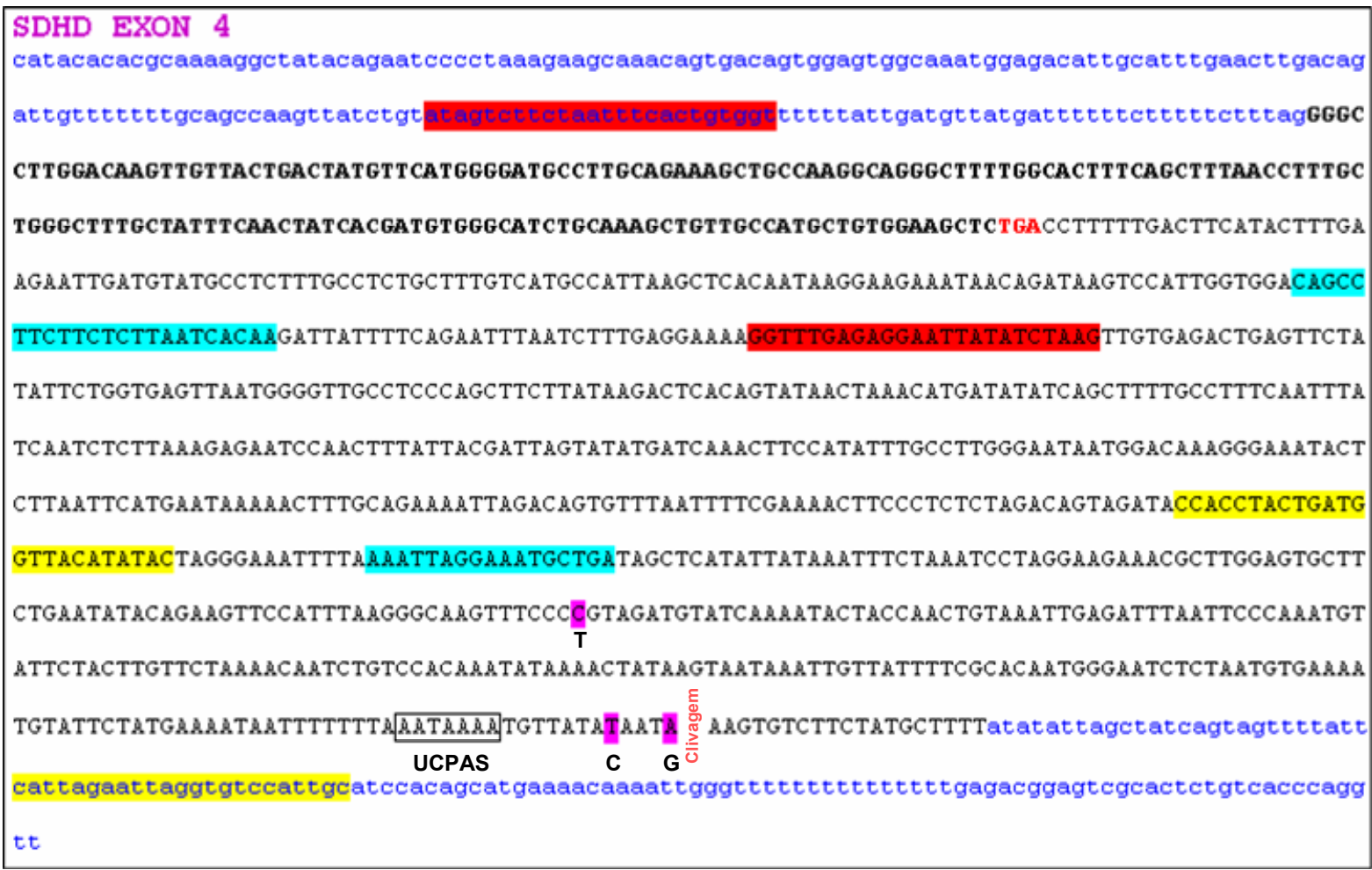

Figura 15: Seqüência do exon 4 e da região 3' não codificante do gene SDHD.

: Variantes alélicas encontradas nos pacientes estudados; : iniciadores do amplicon SDHD 4A; : iniciadores do amplicon SDHD 4B; : iniciadores do amplicon SDHD 4C.

catacac...tttag: intron; GGGCCTT...CTC: exon 4; TGA: códon de parada; CCTTTTT...: região 3' não codificante;

: sinal de poliadenilação - Upstream Core Polyadenylation Signal (UCPAS), Clivagem: Sítio de Clivagem. 
A cauda $\operatorname{Poli}(A)$ é um elemento estrutural e funcional fundamental para os mRNA dos eucariontes, sendo importantes para a regulação da estabilidade do mRNA, da exportação do mesmo do núcleo para o citoplasma, do início da tradução e, possivelmente, para outros eventos celulares. Além disso, o uso de sítios alternativos de poliadenilação é um dos mecanismos pelos quais a expressão gênica é regulada. Sinais de poliadenilação são necessários para o processamento eficiente do mRNA, bem como para o término da transcrição e, provavelmente, para o término da tradução ${ }^{32}$.

A reação de poliadenilação de pré-mRNA de mamíferos é feita em dois estágios: a clivagem endonucleolítica do pré-mRNA e a adição subseqüente da seqüência Poli(A) à extremidade 3' recém-formada. Uma poliadenilação efetiva requer duas seqüências de nucleotídeos, demonstradas na Figura 16. A primeira é um hexâmero altamente conservado, que, em 92\% dos genes humanos que codificam proteínas, corresponde à seqüência AAUAAA no mRNA. Este hexâmero, denominado de Upstream Core Polyadenylation Signal (UCPAS), está localizado de 10 a 30 nucleotídeos 5' ao Sítio de Clivagem, local este onde o mRNA será clivado para a inserção da cauda Poli(A). A segunda seqüência necessária para a poliadenilação efetiva está localizada de 10 a 30 bases 3 ' ao Sítio de Clivagem, é uma região rica em bases GU de seqüência mais variável entre os genes e denominada de Downstream Core Polyadenylation Signal $(\text { DCPAS })^{36}$. Alterações nestas duas regiões podem inibir a poliadenilação bem como o término da transcrição ${ }^{33}$. 


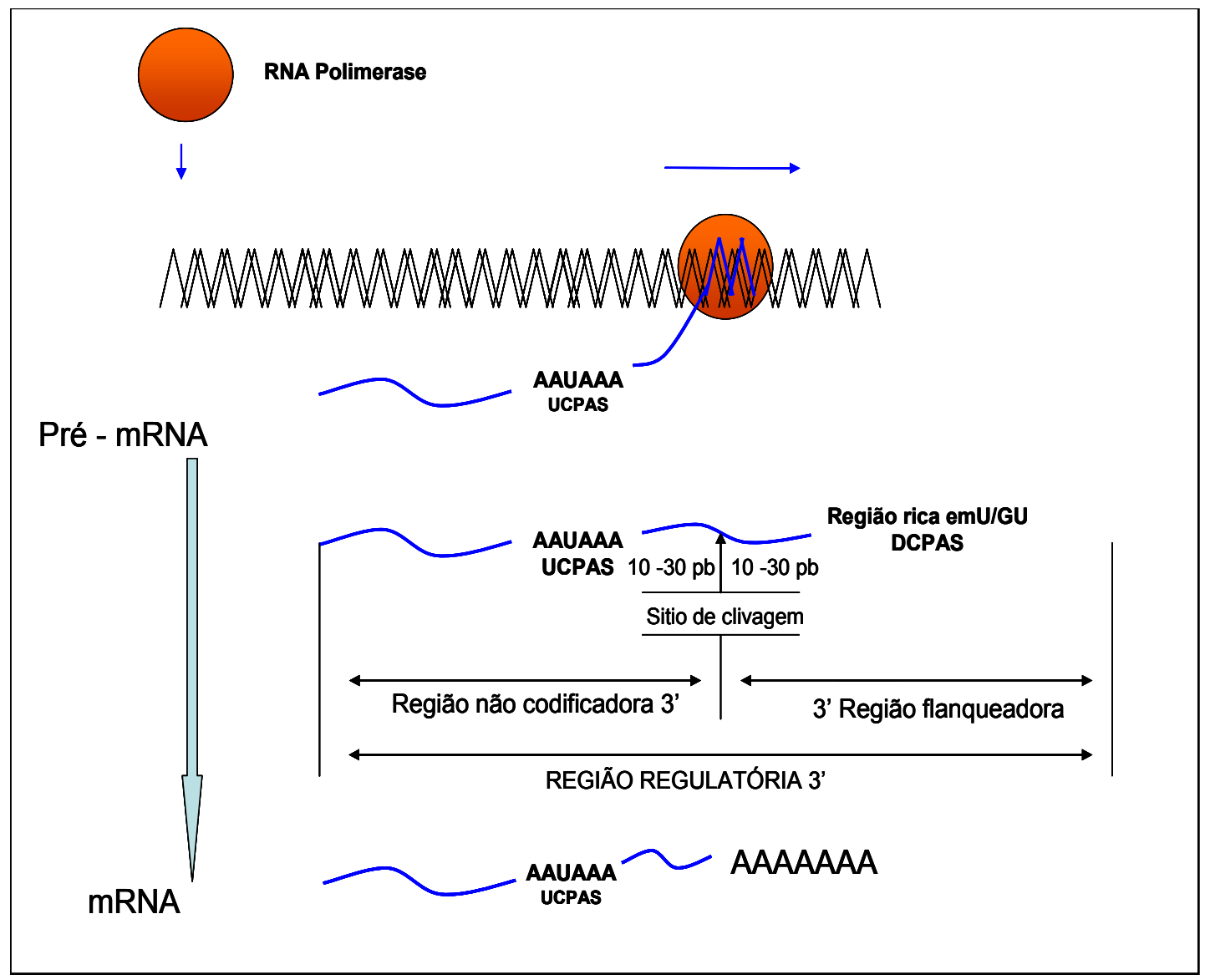

Figura 16: Desenho representativo da reação de poliadenilação de mRNA de mamíferos. A seqüência AAUAAA sinaliza o local onde deve ocorrer a clivagem do RNA mensageiro para inserção da cauda Poli(A) (Sítio de Clivagem), por meio da ligação ao Fator de Clivagem Específico. UCPAS: Upstream Core Polyadenylation Sequence; DCPAS: Downstream Core Polyadenylation Sequence. 
O único papel conhecido da seqüência localizada entre o UCPAS e o Sítio de Clivagem é a participação no processamento da região 3' do mRNA. Estudos recentes de bioinformática identificaram várias modificações nesta região, mais exatamente nos nucleotídeos localizados nas posições -1 e -2, 5' em relação ao Sítio de Clivagem ${ }^{34}$. Nesta região, o dinucleotídeo CA é encontrado em mais de $50 \%$ dos genes humanos e também é o que promove maior eficiência na reação de clivagem do pré-mRNA ${ }^{36}$. Um estudo molecular detalhado substituiu o dinucleotídeo CA pelas 16 possíveis combinações de dois nucleotídeos, e o resultado demonstrou uma ordem de eficiência na clivagem de acordo com a base localizada na posição -1 5' em relação ao Sítio de Clivagem: a base A foi associada com a maior eficiência de clivagem, enquanto a base $G$ foi associada a menor eficiência de clivagem, obtendo-se a seguinte ordem de eficiência: $A>U>C>>G^{36}$. Conclui-se, dessa forma, que substituições de bases nessa posição podem aumentar ou diminuir a eficiência da clivagem do pré-mRNA, o que pode ter repercussões funcionais .

Um polimorfismo encontrado em 1 a $4 \%$ da população caucasiana normal leva à substituição da base $G$ pela base $A$ na posição -1 ' $\mathrm{em}$ relação ao Sítio de Clivagem no gene da protrombina. Este polimorfismo, no qual a base que promove menor eficiência de clivagem $(G)$ é substituída pela base que promove a maior eficiência de clivagem $(A)$, está associado a um maior risco para o desenvolvimento de trombose venosa devido a um aumento na eficiência da clivagem (ganho de função), acúmulo de mRNA e maior síntese protéica, demonstrado em estudos in vitro ${ }^{35}$. Indivíduos 
heterozigotos para o alelo A exibem concentrações de protrombina plasmática aproximadamente $25 \%$ maiores que os homozigotos para o alelo $\mathrm{G}^{36}$.

O polimorfismo c. ${ }^{*} 803 \mathrm{~A}>\mathrm{G}$ no gene SDHD encontrado em sete dos 38 pacientes portadores de feocromocitoma ou paraganglioma nesse estudo determina a substituição da base associada a maior eficiência de clivagem (A) por aquela associada à menor eficiência de clivagem (G) na posição -1 5' ao Sítio de Clivagem, o que poderia ocasionar mecanismo oposto ao ocorrido para o gene da protrombina, ou seja, perda de função pela menor eficiência na clivagem do pré-mRNA do gene SDHD, menor disponibilidade de mRNA maduro e conseqüente diminuição na síntese da proteína SDHD. Esta substituição não altera a estrutura secundária do pré-mRNA do SDHD (Figura 17), o que poderia ser um possível mecanismo de interferência no processamento do pré-mRNA, mas tem grande probabilidade de estar associada a uma repercussão funcional e, portanto, de conferir susceptibilidade ao desenvolvimento de feocromocitomas e paragangliomas. 


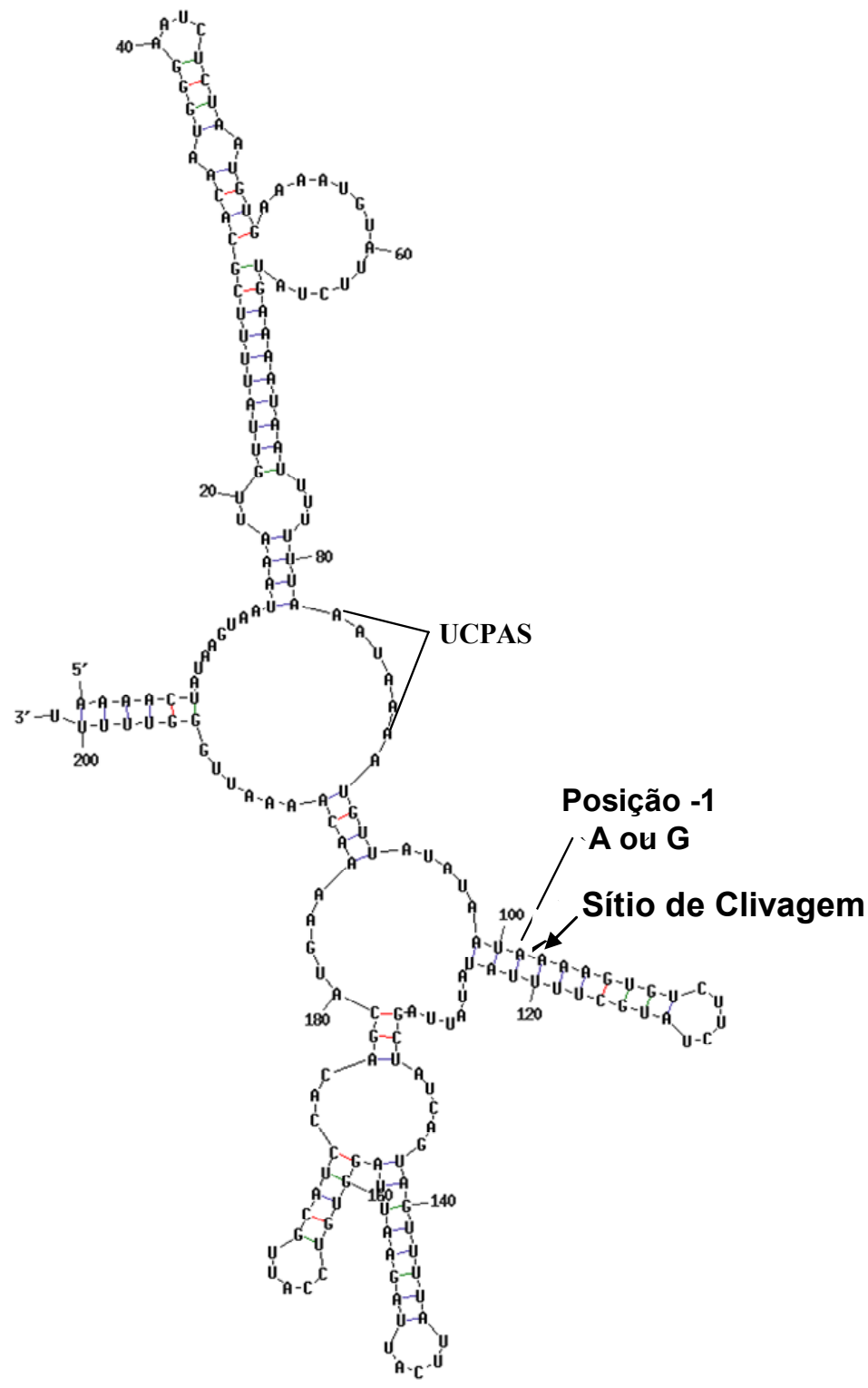

Figura 17: Estrutura secundária proposta para o pré-mRNA transcrito a partir do alelo A do gene SDHD. A estrutura secundária prevista para o alelo $G$ foi idêntica àquela prevista para o alelo $A$. A predição da estrutura secundária foi feita de acordo com o método de Chen et de al ${ }^{36}$,usando o programa mfold descrito por Zuker ${ }^{37}$. UCPAS: Upstream Core Polyadenylation Sequence. 
O polimorfismo c. ${ }^{*} 803 A>G$ foi encontrado em três de 100 indivíduos controles não afetados estudados, sendo que em dois deles, presente em homozigose. Apesar destes três indivíduos apresentarem atualmente idade entre 25 e 30 anos e, portanto, ainda poderem vir a desenvolver feocromocitoma em idade mais avançada, a presença do polimorfismo em homozigose sugere fortemente que apenas este polimorfismo não seja suficiente para determinar a tumorigênese e que outros eventos genéticos precisem ocorrer nos tecidos afetados. É interessante notar que três dos sete pacientes portadores do polimorfismo $c .{ }^{*} 803 A>G$ apresentam outros polimorfismos no gene SDHD (um deles [c.*799 G>C], nunca descrito anteriormente, também na região 3' não codificante), e um dos pacientes também apresenta uma mutação deletéria no gene SDHB (paciente 6). Estudos em séries maiores de pacientes serão necessários para determinar se a concomitância de polimorfismos está presente em parcela significativa dos afetados em relação à população controle não afetada.

Estudos adicionais serão realizados para elucidar a repercussão funcional do polimorfismo c.*803 A>G, tais como: (1) avaliação da eficiência de clivagem do pré-mRNA do gene SDHD em presença do alelo A e do alelo G in vitro; (2) quantidade de mRNA presente na fração polissomal celular de homozigotos para o alelo A e para o alelo $G$, para estimar se a quantidade de mRNA traduzida é menor nos portadores do alelo G; (3) tamanho dos transcritos de mRNA presentes em homozigotos para os alelos A e G; (4) status do gene SDHD nos tumores dos pacientes com o polimorfismo, para evidenciar se houve perda de heterozigose. Como não possuímos RNA dos 
tumores aqui estudados, os experimentos para avaliar o tamanho dos transcritos de mRNA bem como a quantidade de mRNA presente na fração polissomal serão realizados com RNA total extraído de leucócitos de sangue periférico, já que o gene SDHD é de expressão ubíqua.

A freqüência de mutações nesta casuística de tumores esporádicos foi menor que aquela relatada em outros estudos já publicados ${ }^{9,17,18,29,30}$.. Não podemos, no entanto, descartar que tenhamos pacientes portadores de grandes deleções nos genes VHL, SDHB e SDHD, perfazendo um número maior de portadores de alterações nestes genes. Sabe-se que grandes rearranjos genômicos são responsáveis por mais de $20 \%$ dos defeitos genéticos ${ }^{38}$. O seqüênciamento precedido da amplificação da região que se quer estudar é o teste mais utilizado para detecção de mutações, porém, grandes rearranjos moleculares ocorrendo em um dos alelos não são detectados por esta estratégia diagnóstica. Em presença de grandes deleções, o alelo normal é amplificado e seqüenciado, fazendo-se erroneamente o diagnóstico de ausência de mutação, quando, na verdade, somente se analisou o alelo normal e a deleção do outro alelo deixou de ser diagnosticada.

Durante os últimos cinco anos, muitas mutações pontuais inativadoras foram descritas nos genes $\mathrm{SDH}$, tanto para casos de paragangliomas familiares como para casos de paragangliomas e feocromocitomas esporádicos. A ausência de testes de rotina para grandes deleções dificulta o estabelecimento correto da freqüência de mutações e dos rearranjos moleculares que afetam os genes do complexo SDH. Um estudo recente 
rastreou 24 pacientes portadores de paraganglioma ou feocromocitoma com testes negativos para mutações pontuais nos genes RET, VHL, SDHB, SDHD e SDHC e identificou três grandes deleções em heterozigose no gene SDHB ${ }^{32}$. Grandes deleções também foram descritas no gene SDHD, um estudo de Mcwhiney et al. ${ }^{39}$ identificou, além de uma deleção parcial no gene SDHB em uma família, uma deleção completa do gene SDHD em uma segunda família. Grandes deleções também ocorrem em cerca de $20 \%$ a $30 \%$ das famílias portadoras da doença de von Hippel-Lindau ${ }^{40,41}$, mas apenas uma minoria dessas deleções são identificadas ${ }^{42}$.

A baixa freqüência de mutações observada nesse estudo corrobora a importância de se proceder a testes para detecção de grandes deleções gênicas e o achado de um polimorfismo com grande probabilidade de apresentar repercussão funcional na região correspondente ao Sítio de Clivagem do pré-mRNA do gene SDHD ressalta a importância de se rastrear mutações não apenas a região codificadora dos genes, mas também nas regiões não codificadoras que regulam o processamento do mRNA. 
6.CONCLUSÕES 


\section{Conclusões}

Esse estudo evidenciou uma baixa freqüência de mutações nas regiões codificantes dos genes VHL (nenhuma mutação detectada), SDHB (mutação detectada em 5,2\% dos pacientes estudados, 2,6\% trata-se de mutação silenciosa) e SDHD (nenhuma mutação detectada) nesta série de 38 pacientes portadores de feocromocitomas ou paragangliomas esporádicos.

O polimorfismo c. ${ }^{*} 803$ A>G na região 3' não codificante do gene SDHD foi significativamente mais freqüente nos portadores de feocromocitomas e paragangliomas que nos indivíduos controles não afetados e, por modificar o nucleotídeo localizado na posição -1 imediatamente 5' ao Sítio de Clivagem do pré-mRNA do SDHD, pode estar relacionado à etiopatogenia desses tumores. 


\section{ANEXOS}




\title{
HOSPITAL DAS CLÍNICAS
}

ANEXO A

\author{
DA
}

FACULDADE DE MEDICINA DA UNIVERSIDADE DE SÃO PAULO

TERMO DE CONSENTIMENTO LIVRE E ESCLARECIDO

\section{I - DADOS DE IDENTIFICAÇÃO DO SUJEITO DA PESQUISA OU RESPONSÁVEL LEGAL}

1. NOME DO PACIENTE .

DOCUMENTO DE IDENTIDADE N ${ }^{\circ}$ : SEXO :.$M \quad F$

DATA NASCIMENTO: $. / \ldots .$.

ENDEREÇO CIDADE

CEP:. TELEFONE: DDD $\mathrm{N}^{\circ}$......APTO:

2.RESPONSÁVEL LEGAL

NATUREZA (grau de parentesco, tutor, curador etc.)

DOCUMENTO DE IDENTIDADE : SEXO: $M \quad F$

DATA NASCIMENTO.: I..............

ENDEREÇO:

APTO:

BAIRRO:

CIDADE:

CEP:

TELEFONE: DDD

)

\section{II - DADOS SOBRE A PESQUISA CIENTÍFICA}

1. TíTULO DO PROTOCOLO DE PESQUISA: Rastreamento de Mutações nos Genes VHL, SDHB e SDHD em pacientes Portadores de Feocromocitoma ou também, paraganglioma esporádico.

2. PESQUISADOR:. Dra. Maria Lúcia C. Corrêa Giannella

CARGO/FUNÇÃO: Professora Doutora da FMUSP

INSCRIÇÃO CONSELHO REGIONAL Nº 62926

UNIDADE DO HCFMUSP: Disciplina de Endocrinologia do Departamento de Clínica Médica

3. AVALIAÇÃO DO RISCO DA PESQUISA:

SEM RISCO
RISCO MÍNIMO $\quad x$
RISCO BAIXO
RISCO MAIOR

(probabilidade de que o indivíduo sofra algum dano como consequência imediata ou tardia do estudo) 


\section{III - REGISTRO DAS EXPLICAÇÕES DO PESQUISADOR AO PACIENTE OU SEU REPRESENTANTE LEGAL SOBRE A PESQUISA, CONSIGNANDO:}

\section{Justificativa e objetivos da pesquisa.}

Você é portador de feoromocitoma e/ou, paraganglioma, um tumor produtor de noradrenalina e adrenalina, e já foi operado para a retirada deste tumor. $A$ grande maioria dos feocromocitomas ocorrem esporadicamente, porém, em $10 \%$ dos casos, os feocromocitomas ocorrem juntamente com outras manifestações clínicas, em síndromes que atingem várias pessoas de uma mesma família, sendo, portanto, consideradas doenças hereditárias. Dentre estas síndromes, as principais são: a Neoplasia Endócrina Múltipla (NEM) do tipo IIA e a doença de von Hippel-Lindau (VHL). Um estudo internacional feito recentemente mostrou que $11 \%$ dos portadores de feocromocitoma esporádico apresentavam alterações no gene $\mathrm{VHL}$, e que, 4\% apresentam mutações no gene SDHB e 4\% no gene SDHD portanto, embora ainda não apresentassem as outras manifestações clínicas desta síndrome, poderiam apresentar estas manifestações em um futuro próximo ou ainda, estas manifestações poderiam aparecer em outros familiares. O objetivo desta pesquisa é procurar alterações (conhecidas por mutações) nos genes VHL, SDHB e SDHD dos pacientes portadores de feocromocitoma e/ou paraganglioma esporádicos acompanhados no Serviço de Endocrinologia do Hospital das Clínicas da FMUSP para que possamos identificar pacientes e seus familiares que apresentem alto risco para o aparecimento das outras manifestações clínicas características da doença de Von Hippel-Lindau, para que sejam diagnosticados e tratadas precocemente.

\section{Procedimentos que serão utilizados e propósitos, incluindo a identificação dos procedimentos que são experimentais}

Caso você concorde em participar deste estudo, vamos colher uma amostra de seu sangue por meio de uma punção na veia de seu braço para a extração do material genético (DNA) onde será feito o estudo de mutações nos genes VHL, SDHB e SDHD. No caso de se detectar uma mutação no seu gene, uma amostra de sangue de seus familiares de primeiro grau também deverá ser coletada para a pesquisa da mutação.

\section{Desconfortos e riscos esperados}

O único desconforto que você sentirá será uma picada no seu braço para a retirada do sangue onde será realizada a pesquisa da mutação. Os riscos deste procedimento são mínimos, como a formação de hematomas ou pequeno sangramento local. 


\section{Benefícios que poderão ser obtidos}

Você terá a chance de ter o diagnóstico precoce e, portanto, um tratamento precoce de outras manifestações clínicas da Doença de von Hippel-Lindau caso você seja portador da mutação no gene VHL. Da mesma forma, como se trata de uma doença hereditária, se você for portador da mutação, seus familiares de primeiro grau também serão pesquisados e poderão ter o diagnóstico e o tratamento precoces.

\section{Procedimentos alternativos que possam ser vantajosos para o indivíduo}

A única forma de se fazer o diagnóstico da mutação no gene do VHL para o diagnóstico precoce da Doença de von Hippel-Lindau é por meio do estudo do DNA. O procedimento alternativo para se fazer o diagnóstico dessa doença é a realização periódica de exames de imagem (tomografia computadorizada, ressonância magnética) para a detecção de outros tumores que podem aparecer nesta doença (de rins, de pâncreas, de sistema nervoso central, etc...)

\section{IV - ESCLARECIMENTOS DADOS PELO PESQUISADOR SOBRE GARANTIAS DO SUJEITO DA PESQUISA:}

1. acesso, a qualquer tempo, às informações sobre procedimentos, riscos e benefícios relacionados à pesquisa, inclusive para dirimir eventuais dúvidas.

2. liberdade de retirar seu consentimento a qualquer momento e de deixar de participar do estudo, sem que isto traga prejuízo à continuidade da assistência.

3. salvaguarda da confidencialidade, sigilo e privacidade.

4. disponibilidade de assistência no HCFMUSP, por eventuais danos à saúde, decorrentes da pesquisa.

V. INFORMAÇÕES DE NOMES, ENDEREÇOS E TELEFONES DOS RESPONSÁVEIS PELO ACOMPANHAMENTO DA PESQUISA, PARA CONTATO EM CASO DE INTERCORRÊNCIAS CLÍNICAS E REAÇÕES ADVERSAS.

VI. OBSERVAÇÕES COMPLEMENTARES: 


\section{VII - CONSENTIMENTO PÓS-ESCLARECIDO}

Declaro que, após convenientemente esclarecido pelo pesquisador e ter entendido o que me foi explicado, consinto em participar do presente Protocolo de Pesquisa

São Paulo,

de

de 2003

assinatura do sujeito da pesquisa ou responsável legal

assinatura do pesquisador (carimbo ou nome Legível) 
8. REFERÊNCIAS BIBLIOGRÁFICAS 


\section{Referências bibliográficas}

1 Vrezas I, Willenberg HS, Bornstein SR. Adrenal, Cortex, development, anatomy, physiology. In Chrousus G. Adrenal Physiology and Diseases, 2003. Disponível na internet: http://www.endotext.com/adrenal/adrenal1/ adrenalframe1.htm

2 Cotran RS, Kumar V, Collins T. O Sistema Endócrino, pág. 1003. In Patologia Estrutural e Funcional. Editora Guanabara Koogan S.A., 6edição. Rio de Janeiro, 1999

3 Pereira MAA, Halpern A. Sistema cromafim, cap. 12, pág. 571. In Wajchenberg BL: Tratado de Endocrinologia Clínica. Editora Roca Ltda, $1^{\circ}$ edição. São Paulo, 1992

4 Vilar L, Machado AC, Feocromocitomas, diagnóstico e tratamento, cap. 27, parte IV, pág. 347. In Vilar L et al, Endocrinologia Clínica. Medsi editora Médica e Científica. $2^{\circ}$ edição. Rio de Janeiro, 2001

5 Bravo EL, Tagle R: Pheochromocytoma: State of the art and future prospects. Endocr Rev, 2003; 24:539-553 
6 Elder EE, Elder G, Larsson C. Pheochromocytoma and functional paraganglioma syndrome: No longer the $10 \%$ tumor. Journal of Surgical Oncology, 2005;89:193-201

7 DeLellis RA, Lloyd RV, Heitz PU, Eng C eds.Pathology and Genetics, Tumours of Endocrine Organs, In: World Health Organization Internacional Histological Classification of Tumors, Oxford University Press, p 159. 2004

8 Edstrom Elder E, Hjelme Skog A, Hoog A, et al: The management of benign and malignant pheochromocytoma and abdominal paraganglioma. Eur J Surg Oncol, 2003; 29:278:283

9 Dannenberg $H$, Dinjens WNM, Abbou M, van Hurk H, PauwBKH, Mouwen D, Mooi WJ,and Krijger RR. Frequent germ-line succinato dehydrogenase subunit $D$ gene mutations in patients with apparently sporadic parasympathetic paragangliomas. Clin Cancer Res, 2002;8:2061-2066

10 Inabnet WB, Caragliano P, Pertsemlidis D. Pheochromocytoma: inherited associations, bilaterality, and cortex preservation. Surgery 2000;128:1007-1011 
11 Bryant J, Farmer J, Kessler LJ, Townsend RR, Nathanson KL:

Pheochromotytoma: The expanding genetic differential diagnosis. J Natl Cancer Inst, 2003; 95:1196-1204

12 Dahia PL, Hao K, Rogus J, Colin C, Pujana MA, Ross K, Magoffin D, Aronin N, Cascon A, Hayashida CY, Li C, Toledo SP, Stiles CD; Familial Pheochromocytoma Consortium. Novel pheochromocytoma susceptibility loci identified by integrative genomics. Cancer Res, 2005; 65(21):96519658 Lonser RL, Glenn GM, Walter MC et al. von Hippel-Lindal disease. The Lancet, 2003; 361:2059-67

Hes FJ, Ppener JWMH, Lips CJM. Pheocromocytoma in von HippelLindau disease. J Clin Endocrinol Metab, 2003; 88:969-74

Klein B, Weirich G, Brauch H. DHPLC - based germiline mutation screening in the analysis of the VHL tumor supressor gene: usefulness and limitations. Hum Genet 2001; 108: $376-84$ Hes F J, Hoppener J W N, Lips CJM. Pheochromocytoma in von HippelLindau disease. J Clin Endocrinol Metab, 2003; 88(3):969-974 
17 Gimenez-Roqueplo AP, Favier J, Rustin P, Rieubland C, Crespin M, Nau V, Van Kien PK, Corvol P, Plouin PF and Jeunemaitre X. Mutations in the SDHB gene are associated with extra-adrenal and/or malignant phaeochromocytomas. Cancer Research, 2003; 63:5615-5621

Pawlu C, Bausch B and Neumann HPH. Mutations of the SDHB and SDHD genes. Familial Cancer, 2005; 4:49-54

Pollard PJ, Brière JJ, Alam NA, Barwell J, Barclay E, Wortham NC, Hunt T, Mitchell M, Olpin S et al. Accumulation of Krebs cycle intermediates and over-expression of HIF1a in tumours wich result from germline $\mathrm{FH}$ and SDH mutations. Human Molecular Genetics, 2005; 14:2231-2239

20 Astuti D, Latif F, Dallol A, Dahia PLM, Douglas F, George E, Sköldberg F, Husebye ES, Eng C and Maher ER. Gene mutations in the succinate dehydrogenase subunit SDHB cause susceptibility to familial pheochromocytoma and to familial paraganglioma. Am J Hum Genet, $2001 ; 69: 49-54$

21 Baysal BE. Herditary paraganglioma targets diverse paraganglia. J Med Genet, 2002; 39:617-622

Hensen E F, Jordanova ES, van Minderhout IJHM, Hogendoorn PCW, Taschner PEM, van der Mey AGL, Devilee P, Cornelisse CJ. Somatic 
loss of maternal chromosome 11 cause parent-of-origin-dependent inheritance in SDHD-linked paraganglioma and pheochromocytoma families. Oncogene, 2004; 23:4076:4083.

Newman HP, Peczkowska M, Bausch B, McWhinney SR, Muresan M, Buchta M, Franke G, Klisch J, Bley TA, Hoergele S, Boedeker CC, Opocher G, Shipper J, Januszewicz A, Eng C, European - American Paraganglioma Study GroupDistict clinical features of paraganglioma syndromes associated with SDHB and SDHD gene mutations. JAMA, 2004; 292: 943:951.

Newman HP, Peczkowska M, Bausch B, McWhinney SR, Muresan M, Buchta M, Franke G, Klisch J, Bley TA, Hoergele S, Boedeker CC, Opocher G, Shipper J, Januszewicz A, Eng C, European - American Paraganglioma Study Group. Distict clinical features of paraganglioma syndromes associated with SDHB and SDHD gene mutations. JAMA, 2004; 292:943-951 Genetic Aspects of pheochromocytoma. Endocrine regulations, 2001; $35: 43-52$ 
${ }^{26}$ Mulligan LM, Kwok JB, Healey CS, Eldson MJ, Eng C, Gardner E, et al. Germ - line mutations of the RET proto-oncogene in multiple endocrine neoplasia type 2A. Nature, 1993; 363:458-60

27 Brandi ML, Gagel RF, Angeli A, Bilezikian JP, Beck-Peccoz P, Bordi C, Conte-Devolx B , Falchetti A, Gheri RG, Libroia A et al. Consensus Guidelines for Diagnosis and Therapy of MEN Type 1 and Type 2. J Clin Endocrinol Metab, 2001; 86(12):5658-5671

Opocher G, Conton P, Schiavi F, Macino B, Mantero F. Pheochromocytoma in Von Hippel-Lindau disease and neurofibromatosis type 1. Familial Cancer, 2005; 4:13-16

29 Neumann $\mathrm{HPH}$, Bausch B et al: Germ-line mutations in nonsyndromic pheochromocitoma. N Engl J Med, 2002; 346:1459 - 66

30 Amar L, Bertherat J, Baudin E, Ajzenberg C, Paillerets BB, Chabre O, Chamontin B, Delemer B, Giraud S et al: Genetic testing in pheochromocytoma or functional paraganglioma. J Clin Oncol, 2005; 23:8812-8818

31 Klein B, Weirich G, Brauch H (2001). DHPLC germline mutation screening in the analysis of the VHL tumor suppressor gene: usefulness limitations. Hum Genet, 2001; 108:376-384 
32 Zarudnaya MI, Kolomiets IM, Potyahaylo AL, Hovorun DM. Downstream elements of mammalian pre-mRNA polyadenylation signals: primary, secondary and higher-order structures. Nucleic Acids Res, 2003 Mar $1 ; 31(5): 1375-86$

Batt DB, Luo Y, Carmichael GG. Polyadenilation and transcription termination in gene constructs containing multiple tendem polyadenylation signals. Nucleic Acids Research, 1994; (22)14:2811-2816

Hu J, Lutz CS, Wilusz J, Tian B. Bioinformatic identification of candidate cis-regulatory elements involved in humamRNA polyadenilation. RNA, 2005; 11:1485-1493. MW, Kulozik AE (2001) Increased efficiency of mRNA 3' end formation: a new genetic mechanism contributing to hereditary thrombophilia. Nat Genet, 28:389-392

Chen JM, Ferec C, Cooper DN. A systematic analysis of diseaseassociated variants in the 3'regulatory regions of human protein-coding genes I: general principles and overview. Hum Genet, 2006; 120:1-21 
Zuker M. Mfold web server for nucleic acid folding and hybridization prediction. Nucleic Acids Res, 2003;31(13):3406-15.

38

Cascon A, Montero-Conde C, Ruiz-Llorente S, Mercadillo F, Letón R, Rodriguez-Antona C, Martinez-Delgado B, et al.: Gross SDHB delections in patients with paraganglioma detected by multiplex PCR: A possible hot spot? Genes, chromosomes and Cancer, 2006; 45:213-219

39 Mcwhinney Sr, Pilarski Rt, Forrester Sr, Schneider Mc, Sarquis Mm, Dias Ep, Eng C: Large Germline Deletions of Mitochondrial Complex II Subunits $S D H B$ and $S D H D$ in hereditary Paraganglioma. The Journal of Clinical Endocrinology e Metabolism 2004; 89(11):5694-5699

40 Maher ER, Webster AR, Richards FM, et al. Phenotypic expression in von Hippel-Lindau disease: correlationswith germline VHL gene mutations. $J$ Med Genet 1996; 33:328-332

41 Zbar B, Kishida T, Chen F, et al. Germline mutations in the von HippelLindau disease (VHL) gene in families from North America, Europe, and Japan. Hum Mutat 1996;8:348-357

42 Hoebeeck J, van der Luijt R, Poppe B, Smet ED, Yigit N, Claes K, et al: Rapid detection of VHL exon deletions using real-time quantitative PCR. Laboratory Investigation 2005; 85: 24-33 